\title{
Environmental impact on the mechanical properties of Porites spp. corals
}

\author{
Molly A. Moynihan ${ }^{1,2}$ (1) Shahrouz Amini ${ }^{3,4}$ (1) Nathalie F. Goodkin ${ }^{2,5,6}$ (1) \\ Jani T. I. Tanzil ${ }^{5,7}$ (D) J. Q. Isaiah Chua ${ }^{4}$ ・ Gareth N. Fabbro ${ }^{5}$ (D) \\ Tung-Yung Fan $^{8} \cdot$ Daniela N. Schmidt $^{9}$ (i) $\cdot$ Ali Miserez $^{4,10}$ (D)
}

Received: 22 May 2020/Accepted: 23 December 2020/Published online: 8 March 2021

(C) The Author(s) 2021

\begin{abstract}
Despite the economic and ecological importance of corals' skeletal structure, as well as their predicted vulnerability to future climate change, few studies have examined the skeletal mechanical properties at the nanoscale. As climate change is predicted to alter coral growth and physiology, as well as increase mechanical stress events (e.g., bioerosion, storm frequency), it is crucial to understand how skeletal mechanical properties change with environmental conditions. Moreover, while material properties are intimately linked to the chemical composition of the skeleton, no previous study has examined mechanical properties alongside carbonate geochemical composition. Using Porites coral cores from a wide range of reef environments (Thailand, Singapore, Taiwan), we correlated coral's micro-mechanical properties with chemical
\end{abstract}

Topic Editor Morgan S. Pratchett

Supplementary Information The online version supplementary material available at https://doi.org/10.1007/s00338-021-02064-3.

Molly A. Moynihan

moyn0001@e.ntu.edu.sg

1 Earth Observatory of Singapore, Interdisciplinary Graduate School, Nanyang Technological University, Singapore, Singapore

2 Asian School of the Environment, Nanyang Technological University, Singapore, Singapore

3 Department of Biomaterials, Max Planck Institute of Colloids and Interfaces, Potsdam, Germany

4 Center for Biomimetic Sensor Science, School of Materials Science and Engineering, Nanyang Technological University, Singapore, Singapore

5 Earth Observatory of Singapore, Nanyang Technological University, Singapore, Singapore composition. In contrast to previous mechanical measurements of reef-building corals, we document unprecedented variability in the hardness, stiffness, and micro-cracking stress of Porites corals across reef environments, which may significantly decrease the structural integrity of reef substrate. Corals from environments with low salinity and high sedimentation had higher organic content and fractured at lower loads, suggesting that skeletal organic content caused enhanced embrittlement. Within individual coral cores, we observed seasonal variability in skeletal stiffness, and a relationship between high sea surface temperature, increased stiffness, and high-density. Regionally, lower $\mathrm{Sr} / \mathrm{Ca}$ and higher $\mathrm{Mg} / \mathrm{Ca}$ coincided with decreased stiffness and hardness, which is likely driven by increased amorphous calcium carbonate and skeletal organic content. If the coral is significantly embrittled, as measured here in samples from Singapore, faster erosion is expected. A decrease in skeletal stiffness will decrease the quality of reef substrate, enhance the rate of bioerosion by

6 American Museum of Natural History, New York, NY, USA

7 St. John's Island National Marine Laboratory, Tropical Marine Science Institute, National University of Singapore, Singapore, Singapore

8 National Museum of Marine Biology and Aquarium, Pingtung, Taiwan

9 School of Earth Sciences, University of Bristol, Bristol, UK

10 School of Biological Sciences, Nanyang Technological University, Singapore, Singapore 
predators and borers, and increase colony dislodgement, resulting in widespread loss of structural complexity.

Keywords Mechanical response - Porites - Microcracking $\cdot$ Coral geochemistry $\cdot$ Organic content

\section{Introduction}

Scleractinian corals build structures that provide complex three-dimensional habitat of significant ecological and economic value (Moberg and Folke 1999; Pratchett et al. 2008; Graham and Nash 2012). Globally, corals are threatened by increased sea surface temperature (SST), changes in storm intensity, ocean acidification, excess sediment and nutrient input, and sea level rise (HoeghGuldberg et al. 2007; Morgan et al. 2020; Hughes et al. 2018; Hoegh-Guldberg et al. 2017; Silbiger et al. 2018). Such changes in environmental conditions can affect mechanical and microstructural properties of the coral, including calcification rate, skeletal density, and porosity, which may ultimately affect coral health and survival (Fantazzini et al. 2015). Low porosity has been proposed as an adaptive mechanism to enhance skeletal strength in response to high mechanical stress (e.g., wave energy) (Chamberlain 1978) and has been correlated with low SST, increased bulk density, and increased skeletal stiffness (Caroselli et al. 2011; Goffredo et al. 2014). However, environmental conditions do not always have consistent relationships with bulk coral properties. For example, high density bands in coral skeletons can have negative (Caroselli et al. 2011; Tanzil et al. 2016) or positive correlations with SST (Lough and Barnes 1990; Weber et al. 1975). Moreover, bulk observations of coral material properties obscure potential micro- and nano-scale changes in crystal structure, which are directly related to biomineralization.

Coral skeletons are built via extracellular precipitation of calcium carbonate in the form of densely packed orthorhombic aragonite crystals (Muscatine et al. 1997; Tambutté et al. 2007). Recent studies have suggested a multi-step growth mechanism, which begins via amorphous calcium carbonate particle attachment $(\sim 400 \mathrm{~nm})$, followed by an amorphous-to-crystalline phase transition regulated by the organic matrix (largely proteins), which may accelerate mineralization (Mass et al. 2014, 2017; Von Euw et al. 2017; Akiva et al. 2018). As increased organic matter content and crystal disorder are associated with coral centers of calcification (COCs) (Benzerara et al. 2011; Falini et al. 2013; Von Euw et al. 2017), the presence of organic macromolecules in calcification process may also explain corals' ability to form aragonite at much higher rates than synthetic aragonite precipitation, ultimately driving coral growth rates (Mass et al. 2017). Although the origins of these particles and the role of coral biology in calcification are still debated (see DeCarlo et al. 2018), such findings highlight the importance of quantifying coral skeletal properties at scales relevant to crystallization. Yet, despite widespread microscale studies of biomineralization, the mechanical properties (e.g., strength, hardness, stiffness) of coral skeletons are rarely studied at a comparable scale. In contrast with bulk density and porosity, microscale measurements of coral mechanical properties can inform us about the resistance of the skeletal material to deformation and fracture, which is intimately linked with crystal organization and composition, and when combined with environmental information, can tell us how vulnerable this process might be to environmental change.

Young's modulus and hardness are two essential mechanical properties that can be measured for hard materials by depth sensing nanoindentation. The mechanical properties of biomineralized tissues are influenced by the viscoelastic organic matrix, interspersed between the crystalline phase (Wang and Gupta 2011; Liu et al. 2017). Higher organic content usually leads to lower elastic modulus and hardness, but at the same time can also increase fracture toughness (i.e., the resistance against crack propagation) up to a critical threshold (Miserez et al. 2009). However, the role of organic content on the overall strength of hard corals is complex, with no straightforward correlation between organic content and mechanical durability (Amini and Miserez 2013). In scleractinian corals, reported values for organic matrix content vary from 1 to 3\% (Cuif et al. 2004; Dauphin et al. 2006; Falini et al. 2015; Pasquini et al. 2015). These studies were conducted on the upper most part of coral skeletons from pristine, oligotrophic reefs. However, as suggested by Pasquini et al. (2015), corals from a wider range of environments with differing organic matrix content and porosity may have distinct mechanical properties.

Previous studies have found that the Young's modulus was constant between Mediterranean and Red Sea coral species, with average values of approximately $76 \mathrm{GPa}$ for both species (Pasquini et al. 2015). Similarly, Goffredo et al. (2014) found only a small decrease in Young's modulus and hardness over a $5^{\circ}$ decrease in latitude in the Mediterranean. In contrast, Baldock et al. (2014) and Chamberlain (1978) reported bulk-scale differences in compressive strength along horizontal and longitudinal axes of branching coral and between branching and massive morphologies. Yet, these studies were limited in geographic range and did not assess the mechanical properties of a given coral over time, making it difficult to link the relationship between changes in mechanical properties with evolving environmental conditions. 
While environmental effects on mechanical properties are understudied (Ragazzola et al. 2016; Melbourne et al. 2018), it is well documented that environmental conditions can impact the geochemistry of the aragonite (Druffel 1997). For example, the relative amount of $\mathrm{Sr}$ and $\mathrm{Mg}$ incorporated into coral skeletons is related to SST (Smith et al. 1979), while the absolute amount of $P$ and Ba may be influenced by nutrient availability and sedimentation (Mallela et al. 2013; LaVigne et al. 2016). As a result of these relationships, long-lived corals, most commonly Porites lobata and Porites lutea, are used in paleoceanography to reconstruct past climates (Druffel 1997; LaVigne et al. 2016). Despite these established trace element relationships at the millimeter scale, aragonite geochemistry can also vary at the microscale and within skeletal features. For example, compared with adjacent fibrils, $\mathrm{Mg} / \mathrm{Ca}$ in COCs of Pavona clavus increased over $10 \mathrm{mmol} / \mathrm{mol}$ (Meibom et al. 2004), while in Porites lutea, $\mathrm{Mg} / \mathrm{Ca}$ in COCs increased approximately $1 \mathrm{mmol} / \mathrm{mol}$ (Holcomb et al. 2009). Mg acts to stabilize amorphous calcium carbonate (ACC), which is known to exhibit a significantly lower Young's modulus and hardness compared to its crystalline polymorphs (Addadi et al. 2003; Politi et al. 2010).

Although coral skeletal mechanical properties and chemical compositions have a shared dependence on environmental conditions, they have not been examined together in a systematic fashion, with samples from multiple geographical locations. Massive Porites corals are well-suited for combining mechanical and chemical measurements, due to their morphology, growth patterns, and habitat range (Druffel 1997; Grottoli 2001; Cohen and Hart 1997). As numerous paleoclimate studies have been performed using massive Porites, chemical composition and age-modeling methods are well-established (Allison and Finch 2010; LaVigne et al. 2016; Tanzil et al. 2016; Murty et al. 2018). Porites are an important reef-building coral that are found globally on coral reefs (Vernon 2000), as well as in the underlying reef substrate (Johnson et al. 2017). However, despite their importance as a reef-building genus, and their widespread use in coral science, the mechanical properties of Porites have never been measured at the nanoscale. The potential to pair Porites mechanical properties and chemical composition would allow us to infer information not only about past climate, but also about the integrity of past structures. As coral growth and trace element deposition are driven by the formation of nanograin fibers (Mass et al. 2014; Cuif and Dauphin 2005), examining these properties at the nano- and microscales can enhance our understanding of both coral calcification and coral durability, which directly depends on its mechanical properties.
To address these gaps, we examined the mechanical properties and chemical composition of Porites coral cores from three reefs across Asia (Fig. 1). Within the first three to five years of growth from the top of each core, mechanical properties were measured using depth-sensing nanoindentation, and chemical composition was analyzed with laser ablation inductively coupled plasma mass spectrometry (LA-ICP-MS). Additionally, organic content was determined using thermogravimetric analysis (TGA). To our knowledge, this study marks the first reported nanomechanical measurements of Porites coral cores, as well as the first nanoindentation measurements on corals from the Indo-Pacific. With a wide range of environmental, seasonal, and anthropogenic influences in this region, our study seeks to investigate how changes in skeletal geochemistry and mineralization impact structural integrity across multiple spatial and temporal scales. The main aims of this study are to (i) characterize micro- and nano-scale material properties of massive Porites corals over a multiple year period and (ii) determine how these properties vary in response to changing environmental conditions within and between coral cores from a broad geographical range.

\section{Materials and methods}

Six massive Porites coral cores (P. lutea and P. lobata) were collected, from Koh Racha Yai, Phuket, Thailand $\left(7.613105^{\circ} \mathrm{N}, 98.372862^{\circ} \mathrm{E} ; n=2, \mathrm{KRE} \& \mathrm{KRD}\right) ; \mathrm{Kusu}$ Island, Singapore $\left(1.225487^{\circ} \mathrm{N}, 103.860138^{\circ} \mathrm{E} ; n=2\right.$, KUH \& KUSA1); Wanlitung, Taiwan $\left(21.97^{\circ} \mathrm{N}, 120.71^{\circ} \mathrm{E}\right.$; $n=1$, WLT); and Houbihu, Taiwan $\left(21.94^{\circ} \mathrm{N}, 120.75^{\circ} \mathrm{E}\right.$; $n=1, \mathrm{HBH}$ ) (Fig. 1). Cores from Koh Racha Yai, Phuket, Thailand (KRE \& KRD) were approximately $10 \mathrm{~m}$ apart on the reef and sampled on October 3, 2011. Kusu, Singapore cores were collected on December 20, 2011 (KUH), and January 31, 2012 (KUSA1), and were located approximately $300 \mathrm{~m}$ apart. Both Taiwan samples (HBH \& WLT) were cored on May 28, 2013, at reefs approximately $7 \mathrm{~km}$ apart. All cores from Kusu, Singapore and Phuket, Thailand were identified as $P$. lutea. Due to corallite damage, cores from Wanlitung, Taiwan and Houbihu, Taiwan were identified as either $P$. lutea or $P$. lobata. Between these two species, similar growth characteristics have been recorded, and species effects on growth are considered negligible (Lough et al. 1999; Tanzil et al. 2013) (see Supplemental for additional coring information). Cores were grouped by location and identified as Singapore, Thailand, and Taiwan cores throughout the manuscript. 
Fig. 1 a Porites sample sites in Koh Racha Yai, Phuket, Thailand; Kusu Island, Singapore; and Hengchun Township, Taiwan. Cores from b Houbihu (HBH), Nanwan Bay and Wanlitung (WLT), Hengchun Township, Taiwan were approximately $7 \mathrm{~km}$ apart, cores from c Koh Racha Yai, Phuket, Thailand (KRD \& $\mathrm{KRE}$ ) were $<10 \mathrm{~m}$ apart on the same reef, and cores from d Kusu, Island Singapore (KUH \& KUSA1) were approximately $300 \mathrm{~m}$ apart on the same reef
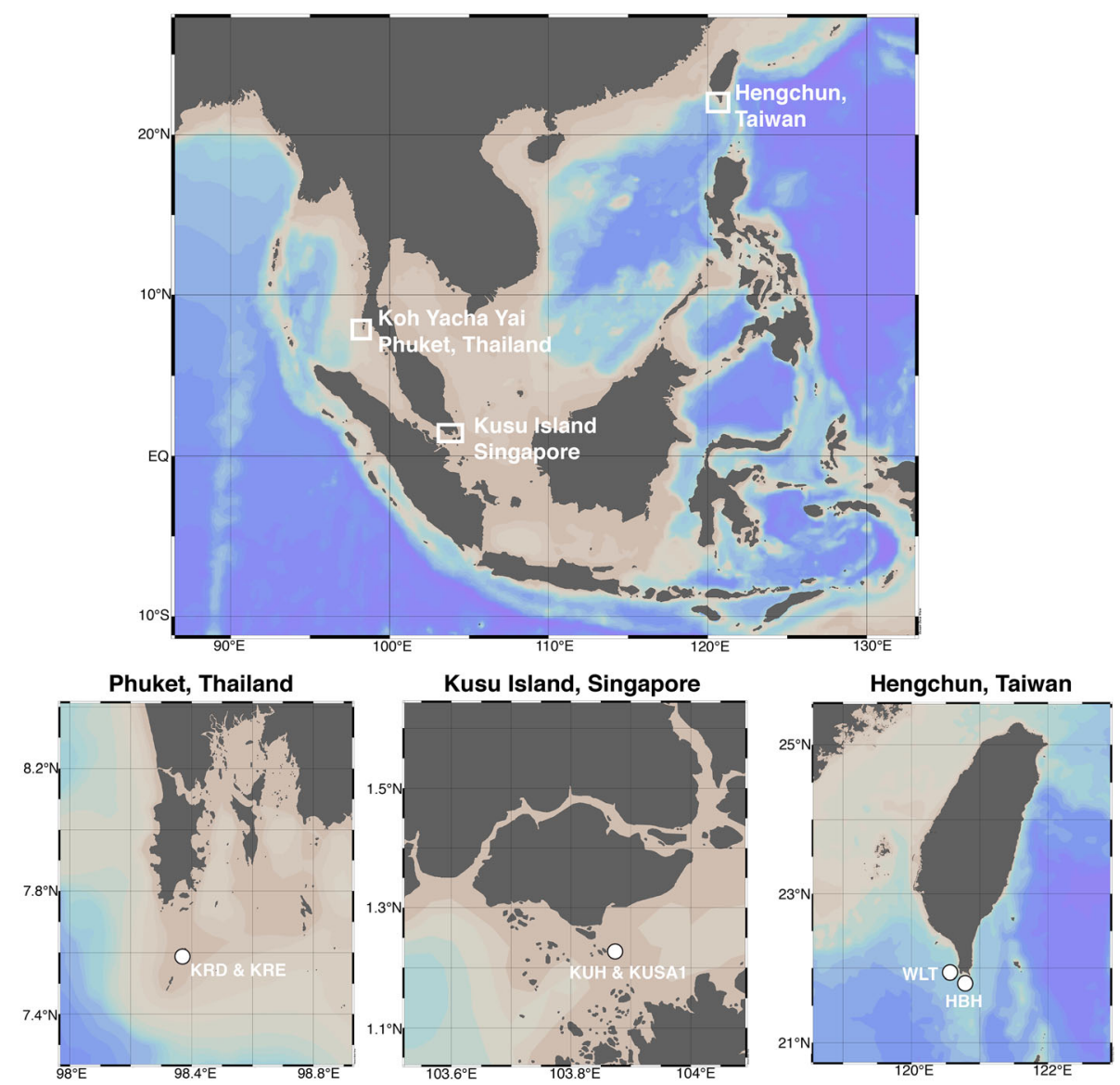

For each site, monthly averaged environmental data were compiled from various satellite and in situ sources, which corresponded with the growing period of each core (Fig. 2; Supplemental; Table S1). Rainfall data were compiled from Tanzil et al. (2016) and the Hengchun weather bureau. Sea surface temperature (SST), ocean current speed \& sea surface salinity (SSS), and photosynthetically available Radiation (PAR) were collected from HadISST (Rayner et al. 2003), SODA POP 3.3.1 (Carton and Giese 2008), and MODIS/Aqua (Acker and Leptoukh 2007), respectively. Significant wave height $\left(\mathrm{H}_{\text {sig }}\right)$ data were gathered from WaveWatch III (WW3) (Tolman 2002) (see Supplemental for more detail). Southern Taiwan is often in the path of typhoons and experiences the strongest seasonal variability between the sites, with the lowest SST and greatest SSS, as well as greater ocean current speed and $H_{\text {sig }}$ (Fig. 2). Singapore is an equatorial reef with limited seasonal variability in SST and SSS, as well as lower PAR, due to high turbidity and sedimentation. While both Phuket (Thailand) and Singapore reefs are in a tropical monsoon climate, Phuket is exposed to swell during the southwest monsoon, driving a seasonal increase in $\mathrm{H}_{\text {sig }}$ (Fig. 2).
The top of each core was selected for analysis, as these time periods corresponded with environmental data availability for each site. Due to the intensive nature and the small scale of the analysis, only the first three to five years of each core were analyzed. Growth years were identified by counting luminescent bands under UV light. The timing of luminescent band and density deposition was verified with alizarin staining and X-ray imaging for Thailand and Singapore (Tanzil et al. 2016), and by a combination of $\mathrm{X}$-ray imaging and $\mathrm{Sr} / \mathrm{Ca}$ age models for Taiwan cores (Ramos 2019). Small fragments, corresponding to approximately one year of growth, were cut along Porites cores, cleaned with ultra-sonication, and embedded in epoxy resin. Fragments were cut parallel to each core's primary growth axis. Cold mounting epoxy resin (EpoFix, Struers) was used to avoid any alteration of the skeletal organic components. Samples were cured under a vacuum. Embedded samples were polished with sandpaper of decreasing mesh size (1000 down to 4000 grit), followed by an alumina colloidal suspension (particle size $40 \mathrm{~nm}$ ) and ultrasonication.

Embedded coral fragments were analyzed for trace elements using LA-ICP-MS (Photon Machines Analyte G2 193 nm ArF excimer, Thermo iCapQ Quadrupole ICP-MS, 

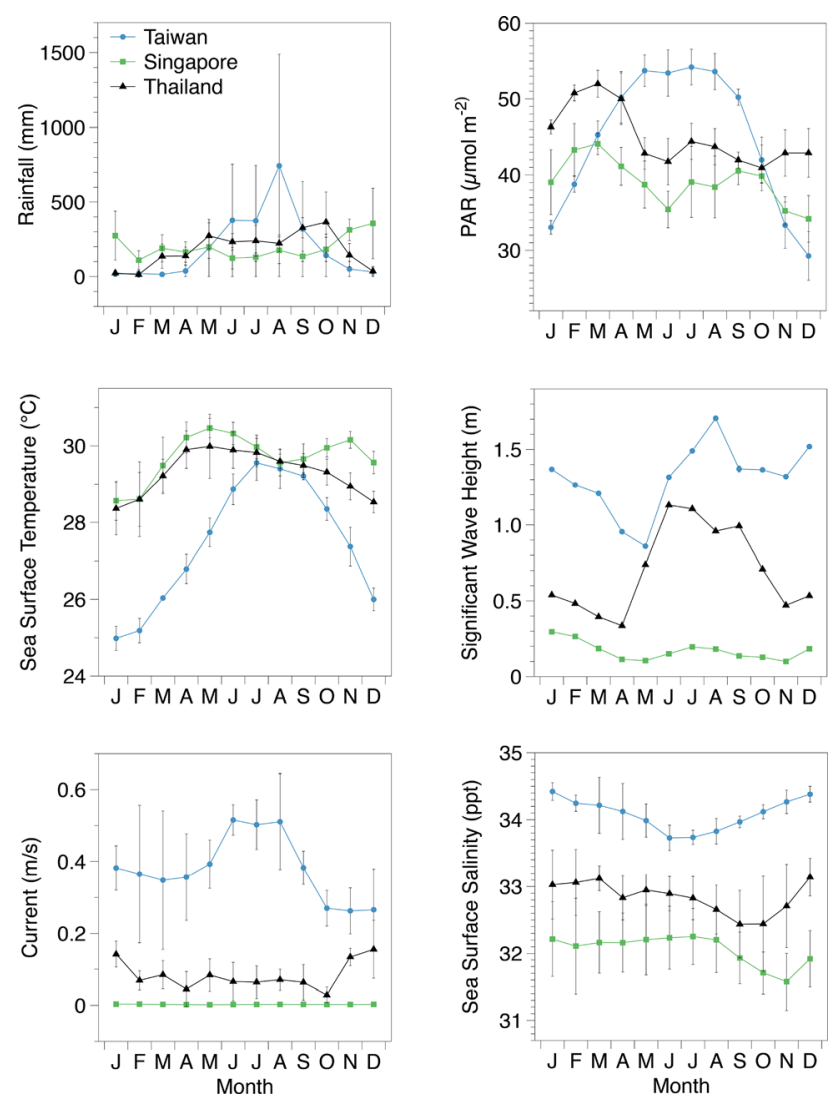

Fig. 2 Monthly average rainfall (mm), photosynthetically activity radiation (PAR) $\left(\mu \mathrm{mol} \mathrm{m}{ }^{-2}\right.$ ), sea surface salinity (SSS), significant wave height $\left(H_{\text {sig }}\right)$, ocean current speed ( $x, y$ directions), and sea surface temperature (SST) data from Taiwan, Singapore, and Thailand coral sites. Error bars represent the monthly standard deviation of each parameter over the relevant growth period of each core used in this study

$10 \mathrm{~Hz}$ ). A line scan with a $100 \times 100 \mu \mathrm{m}$ square beam moving at $5 \mu \mathrm{m} / \mathrm{s}$ was performed along the coral skeleton and ${ }^{24} \mathrm{Mg},{ }^{27} \mathrm{Al},{ }^{31} \mathrm{P},{ }^{43} \mathrm{Ca},{ }^{44} \mathrm{Ca},{ }^{88} \mathrm{Sr},{ }^{111} \mathrm{Cd}$, and ${ }^{137} \mathrm{Ba}$ concentrations were measured. Standard calibration and correction information can be found in the Supplemental Information. Data were normalized to calcium carbonate, and results were then converted into elemental ratios with respect to calcium $(\mathrm{M} / \mathrm{Ca})$. A moving average was used to reduce signal noise. The moving average subset size was determined based on annual growth rate estimations $(1 \mathrm{~cm}$ $\left.\mathrm{yr}^{-1}\right)$ and laser speed $\left(5 \mu \mathrm{m} \mathrm{s}^{-1}\right)$ to represent approximately one week of time $(191 \mu \mathrm{m})$.

Subsequently, nanoindentation measurements were made using a TI 950 TriboIndenter (Hysitron). Indents were performed adjacent to the track of the LA-ICP-MS scan, avoiding the track itself due to damage from the laser. Within each growth year of the coral skeletons, indents were made in 4-6 areas along the laser track, separated by 2-3 mm. Each indentation area comprised of a $40 \times 50 \mu \mathrm{m}$ grid of 20 indents, each separated by $10 \mu \mathrm{m}$. A cono- spherical indenter with a $5 \mu \mathrm{m}$ radius was used to minimize cracking, which we observed with the more commonly used sharp Berkovich diamond indenter. With an average contact depth of $200 \mathrm{~nm}$, the cono-spherical tip compresses an area of approximately $6 \mu \mathrm{m}^{2}$ during each indent. Calibration was performed using either fused quartz or aluminum standards with a Young's moduli of $69 \mathrm{GPa}$ and $72 \mathrm{GPa}$, respectively. Young's modulus was determined using the Oliver and Pharr method (2004) (Fig. 3a; Supplemental). Indents that were out of the calibration range or displayed loading plateaus, also known as "pop-in" events (Fig. 3b), were removed from Young's modulus and hardness calculations, and the remaining indents were averaged (mean $n=15$, ranging from $n=5$ to $n=20$ per indentation grid). The load and depth of pop-in events were used to determine micro-fracture (micro-cracking) stress.

Additional samples from each core were cut with a hand drill (Dremel), adjacent to the annual fragments described above, for thermogravimetric analysis (TGA). Each sample contained homogenized powder from one year of growth. TGA was carried out by first heating coral powder (20 $30 \mathrm{mg}$ ) to a $200^{\circ} \mathrm{C}$ isotherm for $5 \mathrm{~min}$. The sample was then heated at a rate of $10^{\circ} \mathrm{C} / \mathrm{min}$ from 200 to $400^{\circ} \mathrm{C}$ and at a rate of $20^{\circ} \mathrm{C} / \mathrm{min}$ from 400 to $500^{\circ} \mathrm{C}$ (TA instruments TGA Q500). Weight was measured with a precision balance during heating, and $\mathrm{N}_{2}$ gas was used with a balance purge rate of $40 \mathrm{ml} \mathrm{min}^{-1}$ and a sample purge rate of $60 \mathrm{ml} \mathrm{min}{ }^{-1}$. The temperature of maximum weight loss change $\left(T_{\max }\right)$ was determined from the derivative of the weight loss curve. Weight loss percentage was determined in three temperature ranges: $A 1\left(175^{\circ} \mathrm{C}, 225^{\circ} \mathrm{C}\right), A 2$ $\left(T_{\max }-50^{\circ} \mathrm{C}, T_{\max }+50^{\circ} \mathrm{C}\right)$, and $A 3\left(T_{\max }+50^{\circ} \mathrm{C}\right.$, $500^{\circ} \mathrm{C}$ ). The tissue layer was analyzed separately from the rest of the skeleton.

Bulk skeletal density was measured from digitized Xray images taken at the National University Hospital of Singapore (NUH CR, $69 \mathrm{kV}, 5 \mathrm{mAs}$, single exposure) and calibrated using clam standards (see Tanzil et al. 2016). Linear extension rates were determined from annual banding patterns and geochemical data. Average annual density $\left(\mathrm{g} \mathrm{cm}^{-3}\right)$ and linear extension rates $\left(\mathrm{cm} \mathrm{yr}^{-1}\right)$ were multiplied to calculate the calcification rate $\left(\mathrm{g} \mathrm{cm}^{-2} \mathrm{yr}^{-1}\right)$.

Statistics were performed using R software (R 3.6.1) ( R Core Team 2019). Shapiro-Wilk's test was used to test for data normality, and Analysis of Variance (ANOVA) with pairwise comparisons were used to test for differences between sites in bulk density, organic content, and mechanical properties. Correlations between mechanical and chemical properties were determined using Pearson's correlation tests. The down-core time-series of mechanical properties in each core was compared with SST by linearly interpolating SST onto dates from the age-modeled 


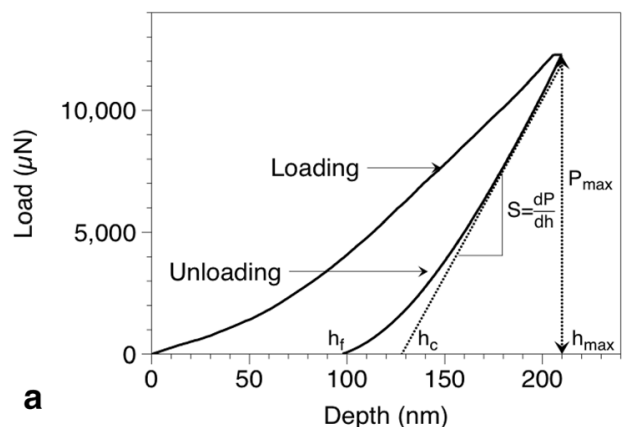

Fig. 3 a Single indentation curve from sample KRD (Thailand), showing loading and unloading curves and parameters $\mathrm{S}$ (stiffness), $\mathrm{P}_{\max }$ (maximum load), $\mathrm{h}_{f}$ (final depth), $\mathrm{h}_{c}$ (contact depth), $\mathrm{h}_{\max }$ (maximum depth). b Multiple indentation curves from a single indentation area $(40 \mu \mathrm{m}$ by $50 \mu \mathrm{m}$ grid). Young's moduli were

Young's modulus of each core. As samples were not from the core's primary growth axis, age-models are given an $x$ error of \pm 1 month. SST and Young's modulus compared using cointegration with an augmented Dickey-Fuller test, which tests for stationary linear combinations between time series datasets. All means are reported with standard deviation (mean $\pm \mathrm{SD}$ ).

\section{Results}

\section{Porites skeletal properties}

Bulk density was lowest in Singapore (KUSA1) $\left(1.13 \pm 0.03 \mathrm{~g} \mathrm{~cm}^{-3} \mathrm{yr}^{-1}\right)$, which differed significantly from all other cores (pairwise $t$ test, Holm adjustment, $p<0.05)$. The highest bulk density was observed in Taiwan (WLT) and Thailand (KRE) $\left(1.27 \pm 0.04 \mathrm{~g} \mathrm{~cm}^{-3} \mathrm{yr}^{-1}\right.$ and $1.27 \pm 0.04 \mathrm{~g} \mathrm{~cm}^{-3} \mathrm{yr}^{-1}$ ). The highest linear extension and calcification rates were found in Singapore (KUSA1) $\left(1.94 \pm 0.12 \mathrm{~cm} \mathrm{yr}^{-1} ; 2.18 \pm 0.17 \mathrm{~cm}^{-2} \mathrm{yr}^{-1}\right)$ and Thailand (KRD) $\quad\left(1.57 \pm 0.14 \mathrm{~cm} \mathrm{yr}^{-1} ; \quad 1.93 \pm 0.10 \mathrm{~cm}^{-2}\right.$ $\left.\mathrm{yr}^{-1}\right)$. Detailed bulk density, linear extension, and calcification rates can be found in the Supplemental (Table S2).

Hardness and Young's modulus were positively correlated across all six coral cores $(r=0.76, p<0.0001$, $n=98$, Pearson's) (Table 1). Young's modulus and hardness of the Taiwan cores (WLT \& HBH) differed significantly from each other ( $t$ test, $p<0.0001)$. No significant differences were found between Young's modulus ( $t$ test, $p=0.07)$ and hardness ( $t$ test, $p=0.71$ ) of Thailand replicate cores (KRE \& KRD), as well as between Young's modulus ( $t$ test, $p=0.06$ ) and hardness ( $t$ test, $p=0.85$ ) of Singapore replicate cores (KUH \& KUSA1). Pop-in events occurred with a significantly higher frequency in Singapore cores, as well as at significantly lower stresses (ANOVA,

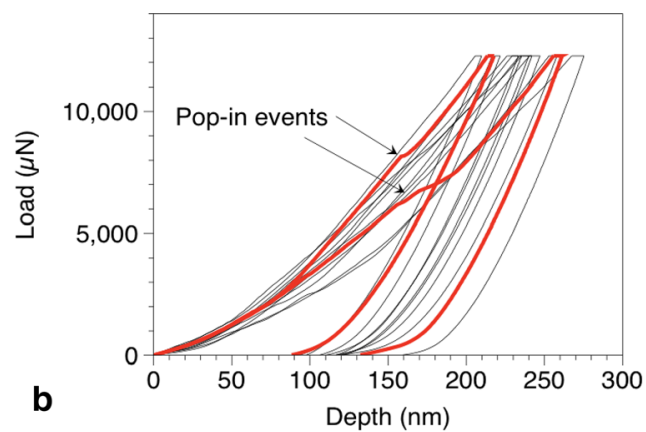

determined from each curve using the Oliver-Pharr method (2004) (Supplemental) and then averaged within each indentation area. Popin events, shown in red, result from free movement of the indenter during cracking and induce displacements which effect $\mathrm{E}$ and $\mathrm{H}$ calculations

Tukey HSD post hoc, $p=0.0001$ ) (Fig. 4a). A decrease in the magnitude of micro-cracking stress was directly correlated with decreasing Young's modulus $(r=0.63$, $p=0.002, n=20)$ and hardness $(r=0.85, p<0.0001$, $n=20$ ) (Fig. 4b).

Trace element $(\mathrm{M} / \mathrm{Ca})$ values ranged from: 3.6$5.7 \mathrm{mmol} / \mathrm{mol} \mathrm{Mg} / \mathrm{Ca} ; 1.04-232.9 \mu \mathrm{mol} / \mathrm{mol} \mathrm{Al} / \mathrm{Ca} ; 23.0$ $897.9 \mu \mathrm{mol} / \mathrm{mol} \mathrm{P} / \mathrm{Ca} ; \quad 8.6-9.5 \mathrm{mmol} / \mathrm{mol} \mathrm{Sr} / \mathrm{Ca} ; \quad 0.01-$ $0.5 \mu \mathrm{mol} / \mathrm{mol} \mathrm{Cd} / \mathrm{Ca}$; and $1.8-161.8 \mu \mathrm{mol} / \mathrm{mol} \mathrm{Ba} / \mathrm{Ca}$. Between the tissue layer and the fully formed skeleton, $\mathrm{P} /$ $\mathrm{Ca}$ and $\mathrm{Ba} / \mathrm{Ca}$ ratios both decreased approximately 5 -fold. $\mathrm{Sr} / \mathrm{Ca}$ and $\mathrm{Mg} / \mathrm{Ca}$ display a significant, negative correlation ( $r=-0.42, p<0.0001, n=103$, Pearson's). Detailed data can be found in Table S3 (Supplemental).

Organic content was highest in the tissue layer, with the main organic components (A2; Fig. 5) having an average content of $2.1 \pm 5.4 \%$, compared with $1.4 \pm 0.07 \%$ in the skeleton (Table 2). The peak temperature of organic matter combustion $(A 2)$ was $286.3 \pm 2.8^{\circ} \mathrm{C}$. In the skeleton (excluding tissue layer), $A 2$ organic content did not differ significantly between replicate cores from the same region ( $t$ test, $p>0.05$ ). When grouped by region, Thailand's $A 2$ organic content was significantly lower than that of Singapore and Taiwan, by an average of $0.14 \%$ and $0.08 \%$, respectively (ANOVA, Tukey HSD post hoc, $p<0.05$; Fig. 5). The sum of organic content $(A 1+A 2+A 3$; Fig. 5) ranged from 2.6 to $6.3 \%$ in the tissue layer and $1.65 \%$ to $2.2 \%$ in the skeleton. In the skeleton (excluding tissue layer), organic content sum differed between Thailand replicate cores (KRE \& KRD) ( $t$ test, $p=0.03$ ), but no difference was found between Singapore's two replicate cores nor between Taiwan's ( $t$ test, $p>0.05$ ). Thailand's sum organic content was lower than Singapore and Taiwan by an average of $0.23 \%$ and $0.15 \%$, respectively (ANOVA, Tukey HSD post hoc, $p<0.05$; Fig. 5). 
Table 1 Average Young's Modulus and Hardness in the fully formed skeleton and tissue layers from six Porites cores ( \pm SD), along with the \% of indents containing pop-in events during loading

\begin{tabular}{|c|c|c|c|c|c|c|c|}
\hline \multirow[t]{2}{*}{ Site } & \multirow[t]{2}{*}{ Core } & \multicolumn{3}{|l|}{ Skeleton } & \multicolumn{3}{|l|}{ Tissue layer } \\
\hline & & $\begin{array}{l}\text { Young's Modulus } \\
(\mathrm{GPa})\end{array}$ & $\begin{array}{l}\text { Hardness } \\
(\mathrm{GPa})\end{array}$ & $\begin{array}{l}\text { Pop-in events } \\
(\%)\end{array}$ & $\begin{array}{l}\text { Young's Modulus } \\
\text { (GPa) }\end{array}$ & $\begin{array}{l}\text { Hardness } \\
(\mathrm{GPa})\end{array}$ & $\begin{array}{l}\text { Pop-in events } \\
(\%)\end{array}$ \\
\hline Wanlitung, Taiwan & WLT & $68.6 \pm 7.6$ & $3.2 \pm 0.4$ & 17.0 & $61.1 \pm 5.9$ & $2.1 \pm 0.4$ & 26.7 \\
\hline Houbihu, Taiwan & $\mathrm{HBH}$ & $40.4 \pm 16.2$ & $1.9 \pm 0.4$ & 24.7 & $61.2 \pm 14.0$ & $2.7 \pm 0.6$ & 15.0 \\
\hline \multirow[t]{2}{*}{ Phuket, Thailand } & KRE & $62.5 \pm 9.3$ & $2.3 \pm 0.2$ & 11.0 & $66.6 \pm 8.9$ & $2.3 \pm 0.0$ & 2.5 \\
\hline & KRD & $45.2 \pm 22.4$ & $2.1 \pm 0.6$ & 24.2 & $76.0 \pm 3.7$ & $3.0 \pm 0.7$ & 25.0 \\
\hline \multirow[t]{2}{*}{ Kusu, Singapore } & KUH & $36.1 \pm 14.1$ & $1.3 \pm 0.4$ & 48.0 & $56.2 \pm 10.4$ & $2.2 \pm 0.2$ & 55.0 \\
\hline & KUSA1 & $46.5 \pm 8.8$ & $1.4 \pm 0.3$ & 53.1 & $53.1 \pm 2.4$ & $1.9 \pm 0.2$ & 33.6 \\
\hline
\end{tabular}
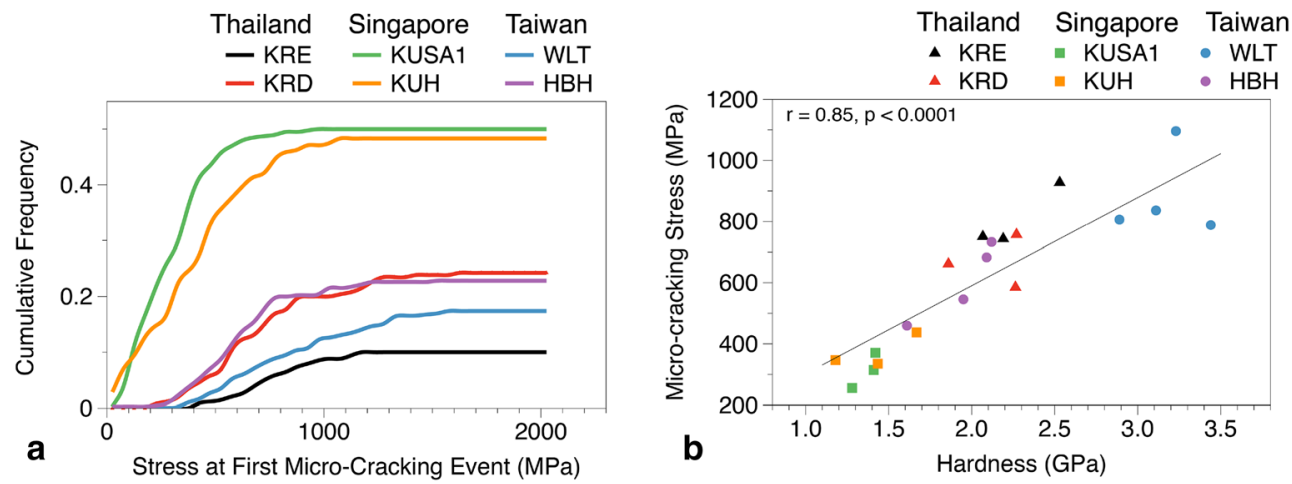

Fig. 4 a Cumulative frequency distribution of the stress (MPa) at which the first observed micro-cracking, or "pop-in," event occurred for each coral core. b Annually averaged micro-cracking stress versus average hardness for each core

\section{Relationships between skeletal properties and environmental conditions}

Young's modulus was age-modeled using a combination of luminescent banding, density banding, and geochemical data, with the assumption of linear seasonal growth (Fig. 6) (Ramos 2019; Tanzil et al. 2016). Linear interpolation revealed a significantly positive correlation of Young's moduli with SST for KRD (Thailand) and WLT (Taiwan) (Table 3). Similarly, Young's modulus and SST were significantly cointegrated at all sites, with the exception of Taiwan core HBH (Table 3).

Combining all cores, Young's modulus $(r=0.33$, $p=0.0008, n=103$, Pearson's) and hardness ( $r=0.31$, $p=0.001, n=103$, Pearson's) displayed a significant, positive relationship with $\mathrm{Sr} / \mathrm{Ca}$ (Table 4; Fig. 7). These relationships were strengthened when data from the tissue layer were removed (Young's modulus \& $\mathrm{Sr} / \mathrm{Ca}: r=0.43$, $p=0.0001, n=75 ;$ Hardness \& Sr/Ca: $r=0.41$, $p=0.0003, n=75$; Fig. 7). In addition, Young's modulus and hardness had significant, negative relationships with $\mathrm{Ba} / \mathrm{Ca}$ (Young's modulus \& $\mathrm{Ba} / \mathrm{Ca}: p=-0.45, p<0.0001$, $n=81$; Hardness \& $\mathrm{Ba} / \mathrm{Ca}: \quad r=-0.34, \quad p=0.002$, $n=81)$. The Thailand core, KRD, exhibited significantly higher $\mathrm{Ba} / \mathrm{Ca}$ values than its replicate (KRE) and all other coral samples. The dotted line in Fig. 7 shows the correlation between all points, excluding KRD (Young's modulus \& $\mathrm{Ba} / \mathrm{Ca}: r=-0.54, p<0.0001, n=72$; Hardness $\&$ $\mathrm{Ba} / \mathrm{Ca}: r=-0.69, p<0.0001, n=72)$. Within an individual core, almost no significant trends were found between $\mathrm{M} / \mathrm{Ca}$ and mechanical properties (Table S4; Supplemental).

Several relationships were also evident between bulk measurements and annually averaged material properties, including a decrease in fracture (cracking) stress and increase in fracture frequency with increasing organic content $\quad(r=-0.51, p=0.02, \quad n=20 ; r=0.61$, $p=0.004, n=20$ ) (Fig. 8; Table 5). A weak relationship was observed between Young's modulus \& sum organic content $(r=-0.50, p=0.02, n=20)$. Including tissue layer data, bulk density displayed a significant correlation with annually averaged Young's modulus $(r=0.49, p=0.01, n=23), \quad$ hardness ( $r=0.54, p=0.007, n=23)$, and micro-cracking stress $(r=0.65, p=0.0009, n=23)($ Fig. 8 ; Table 5), as well as 
Table 2 Organic content (\%) from thermogravimetric analysis from each Porites core. Data from regions $A 2\left(T_{\max }-50{ }^{\circ} \mathrm{C}\right.$, $\left.T_{\max }+50^{\circ} \mathrm{C}\right)$ and the sum of weight loss $(A 1+A 2+A 3)$ are shown (see Fig. 5)

\begin{tabular}{|c|c|c|c|c|}
\hline \multirow[t]{2}{*}{ Site } & \multirow[t]{2}{*}{ Core } & & \multicolumn{2}{|c|}{ Organic content (\%) } \\
\hline & & & $A 2$ & Sum \\
\hline \multirow[t]{2}{*}{ Wanlitung, Taiwan } & WLT & $\mathrm{TL}$ & 2.06 & 3.27 \\
\hline & & S & $1.54 \pm 0.02$ & $1.99 \pm 0.02$ \\
\hline \multirow[t]{2}{*}{ Houbihu, Taiwan } & $\mathrm{HBH}$ & $\mathrm{TL}$ & 2.17 & 2.93 \\
\hline & & $S$ & $1.54 \pm 0.04$ & $1.97 \pm 0.02$ \\
\hline \multirow[t]{4}{*}{ Phuket, Thailand } & KRE & $\mathrm{TL}$ & 1.69 & 2.88 \\
\hline & & $\mathrm{S}$ & $1.44 \pm 0.02$ & $1.74 \pm 0.07$ \\
\hline & KRD & $\mathrm{TL}$ & 1.55 & 2.62 \\
\hline & & $\mathrm{S}$ & $1.47 \pm 0.06$ & $1.93 \pm 0.04$ \\
\hline \multirow[t]{4}{*}{ Kusu, Singapore } & KUH & $\mathrm{TL}$ & 3.26 & 6.32 \\
\hline & & $S$ & $1.64 \pm 0.05$ & $2.13 \pm 0.07$ \\
\hline & KUSA1 & $\mathrm{TL}$ & 1.62 & 3.26 \\
\hline & & $S$ & $1.57 \pm 0.08$ & $2.01 \pm 0.00$ \\
\hline
\end{tabular}

Tissue layer (TL) organic content is shown separately from the annual average of the skeleton $(\mathrm{S})$ below the tissue layer $( \pm \mathrm{SD})$
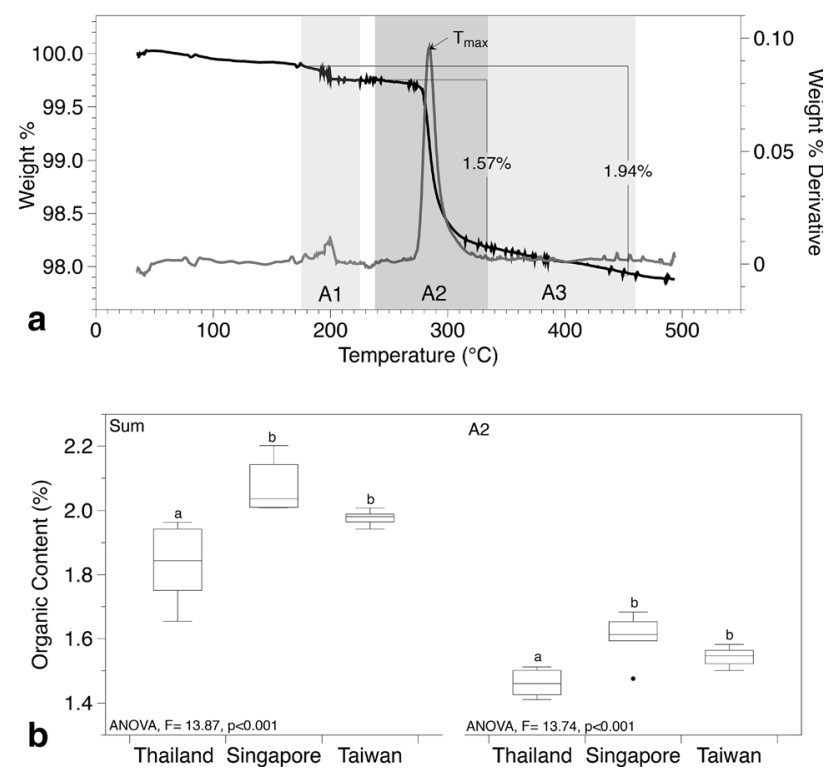

Fig. 5 a Thermogravimetric Analysis (TGA) weight loss from the 2013 growth year of the Taiwan Houbihu core (HBH). Weight loss was divided into three regions based on the weight loss derivative maximum: $A 1\left(175^{\circ} \mathrm{C}, 225^{\circ} \mathrm{C}\right), A 2\left(T_{\max }-50^{\circ} \mathrm{C}, T_{\max }+50^{\circ} \mathrm{C}\right)$, and $A 3\left(T_{\max }+50^{\circ} \mathrm{C}, 500^{\circ} \mathrm{C}\right)$. The sum of weight loss was determined by $A 1+A 2+A 3$. b Organic content (\%) in 6 cores for the sum of all organic material and the major organic peak $(A 2)$, grouped by site (excluding tissue layer organic content)

with $\mathrm{Sr} / \mathrm{Ca}(r=0.50, p=0.017, n=23)$ (Table 4). Within individual coral cores, HBH (Taiwan) was the only core with detectable variation at the annual scale, with sum organic content varying positively with Young's modulus $(r=-0.97, p=0.03, n=4), \quad$ micro-cracking stress $(r=-0.97, p=0.03, n=4), \quad$ and $\quad \mathrm{Ba} / \mathrm{Ca}$ $(r=0.90, p=0.09, n=4)$; however, sample size was limited as organic content was only measured annually.

\section{Discussion}

\section{Nanoindentation results in the context of previous studies}

Young's modulus, hardness, and micro-cracking stress of Porites skeletons varied significantly across environments, as well as within a single location and a single colony. In comparison with other aragonitic biominerals, such as nacre $(E=60-84 \mathrm{GPa}, \quad H=2.7-6.5 \mathrm{GPa}), \quad$ conch $(E=74 \mathrm{GPa}, H=3.3 \mathrm{GPa})$, or pteropods $(E=51.1-$ 85.9 GPa, $H=5.2-5.6 \mathrm{GPa}$ ) (Amini and Miserez 2013; Zhang et al. 2011; Mu et al. 2018), Porites skeletons possessed inferior mechanical properties $(E=62.4 \mathrm{GPa}$, $H=2.0 \mathrm{GPa}$ ). Despite variability within colonies, which was likely driven by seasonal changes in growth and calcification, we observed both site-specific differences and common patterns across sites. For example, micro-cracking frequency was clearly higher in Singapore corals (Fig. 4), while in nearly all corals, Young's modulus and hardness were an average of 1.4 times higher in the recently formed skeleton, commonly referred to as the tissue layer, than the underlying skeleton (Table 1). The large range in mechanical variability observed in this study is rarely found within a single mineral phase of one organism and contradicts previous nanoindentation studies on corals, which report homogenous properties in three scleractinian species (Goffredo et al. 2014; Pasquini et al. 2015). However, discrepancies may be a result of differences in sampling techniques or coral species, as prior studies have mainly focused on temperate coral (Goffredo et al. 2014; Pasquini et al. 2015). Here, although Porites cores were collected at different time points, skeletons were sampled over a multiyear growth period with a high degree of temporal overlap between sampling points, and environmental data were compiled from the corresponding growth period for each core. Consequently, differences in core sampling dates are unlikely to have driven the observed differences between samples.

Our sampling design uniquely distinguished skeletal properties of the tissue layer from those of the underlying skeleton. Nanoindentation, organic content, and geochemical data reported in this study were different in these two regions, with the tissue layer having higher moduli and increased hardness, more organic content, and elevated $\mathrm{Ba} /$ $\mathrm{Ca}$ and $\mathrm{P} / \mathrm{Ca}$ relative to skeletal regions below. Previous 
Table 3 (a) Correlations of age-modeled young's modulus and Sea Surface Temperature (SST) from (a) Singapore cores KUSA1 and KUH, (b) Thailand cores KRD and KRE, and (c) Taiwan cores WLT and $\mathrm{HBH}$

\begin{tabular}{llll}
\hline Site & Core & \multicolumn{2}{l}{ Young's Modulus \& SST } \\
\cline { 3 - 4 } & & $\begin{array}{l}\text { Linear interpolation } \\
\text { (Pearson's) }\end{array}$ & $\begin{array}{l}\text { Cointegration } \\
\text { (Aug. Dickey-Fuller) }\end{array}$ \\
\hline Wanlitung, Taiwan & WLT & $r=0.48, p=0.02^{*}$ & $p=0.01^{*}$ \\
Houbihu, Taiwan & HBH & $r=0.24, p=0.26$ & $p=0.48$ \\
Phuket, Thailand & KRE & $r=0.25, p=0.38$ & $p=0.01^{*}$ \\
Kusu, Singapore & KRD & $r=0.56, p=0.04^{*}$ & $p=0.01^{*}$ \\
& KUH & $r=0.36, p=0.24$ & $p=0.01^{*}$ \\
& KUSA1 & $r=0.13, p=0.59$ & $p=0.04^{*}$ \\
\hline
\end{tabular}

Asterisks denote significance $\left(0.01<\mathrm{p} \leq 0.05^{*}\right)$
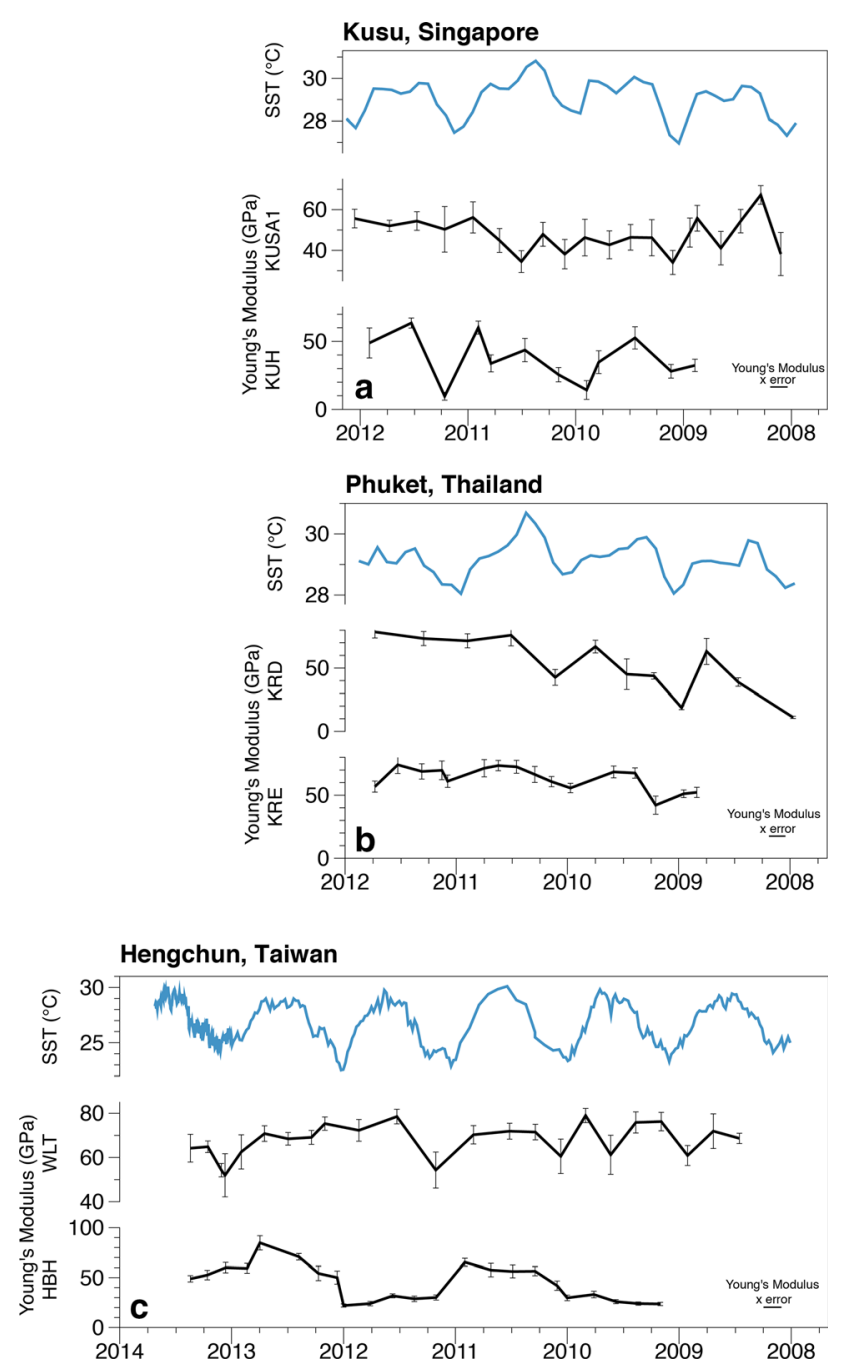

Fig. 6 Age-modeled Young's modulus and Sea Surface Temperature (SST) from a Singapore cores KUSA1 and KUH, b Phuket, Thailand cores KRD and KRE, and $\mathbf{c}$ Hengchun, Taiwan cores WLT and HBH

nanoindentation measurements of scleractinian corals (Goffredo et al. 2014; Pasquini et al. 2015) and TGA (Falini et al. 2013) made no distinction between these two layers, with the exception of TGA by Cuif et al. (2004), who sampled only the upper skeleton region. Hemispherical Porites colonies, along with other massive corals, have a small ratio of living tissue to skeletal volume. For example, in a massive Porites colony, the non-living skeleton can comprise $>98 \%$ of the structure, whereas a cylindrical shaped Acropora branch contains approximately $60 \%$ non-living skeleton. ${ }^{1}$ Given the distinct properties observed between these two skeletal regions, we recommend that it is fundamentally important to differentiate both regions, particularly in the context of the structural integrity of reef framework.

Additionally, in contrast with existing nanoindentation studies of scleractinian coral (Pasquini et al. 2015; Goffredo et al. 2014) that used a sharp Berkovich indenter $\left(\sim 100 \mathrm{~nm}\right.$ tip, opening angle $\left.=142.38^{\circ}\right)$, we purposely selected a cono-spherical indenter ( $5 \mu \mathrm{m}$ radius) to reduce internal contact stresses during indentation. While the Berkovich geometry is commonly used in indentation studies of biominerals, the cono-spherical tip postpones inelastic deformation and minimizes micro-cracking events for a given applied load, which can be detected as displacement discontinuities in the load-displacement curves (i.e., pop-in events) (Fig. 4b) (Van Vliet et al. 2003; Kearney et al. 2006). In addition, material brittleness, which drives erosion through micro-damage, can be more readily differentiated between different samples by using the cono-spherical geometry, due to the delay in microcracking events, even in relatively brittle materials. Such micro-cracking events were particularly prevalent in all Singapore samples, occurring in nearly $50 \%$ of all indent loading curves (Fig. 4a). As Singapore corals also had the lowest modulus and hardness (Table 1), our results indicated a direct correlation between these parameters (Fig. 4b).

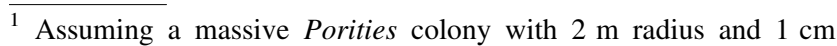
thick tissue layer, and Acropora branches of $6 \mathrm{~cm}$ length, $1 \mathrm{~cm}$ diameter, and $2 \mathrm{~mm}$ thick tissue layer.
} 
Table 4 Trace element ratio correlations with skeleton mechanical and physical properties from the combined 6-core dataset, excluding the tissue layer

\begin{tabular}{lllll}
\hline $\mathrm{M} / \mathrm{Ca}$ & Young's modulus & Hardness & Density & Linear extension \\
\hline $\mathrm{Mg} / \mathrm{Ca}$ & $r=-0.28, p=0.01^{*}$ & $r=-0.26, p=0.02^{*}$ & $r=0.05, p=0.83$ & $r=0.11, p=0.65$ \\
$\mathrm{Al} / \mathrm{Ca}$ & $r=0.07, p=0.53$ & $r=0.16, p=0.15$ & $r=0.17, p=0.48$ & $r=-0.21, p=0.41$ \\
$\mathrm{P} / \mathrm{Ca}$ & $r=0.10, p=0.40$ & $r=0.04, p=0.75$ & $r=0.18, p=0.65$ & $r=0.02, p=0.95$ \\
$\mathrm{Sr} / \mathrm{Ca}$ & $r=0.43, p<0.0001^{* * *}$ & $r=0.41, p=0.0002^{* * *}$ & $r=0.50, p=0.65^{*}$ & $r=-0.47, p=0.05^{*}$ \\
$\mathrm{Ba} / \mathrm{Ca}$ & $r=-0.45, p<0.0001^{* * *}$ & $r=-0.34, p=0.002^{* *}$ & $r=-0.02, p=0.92$ & $r=0.44, p=0.06$ \\
$\mathrm{Cd} / \mathrm{Ca}$ & $r=0.32, p=0.003^{* *}$ & $r=0.45, p=0.003^{* * *}$ & $r=0.32, p=0.19$ & $r=-0.32, p=0.19$ \\
\hline
\end{tabular}

Asterisks denote significance $(0.01<\mathrm{p} \leq 0.05 *, 0.001<\mathrm{p} \leq 0.01 * *, \mathrm{p} \leq 0.001 * * *)$
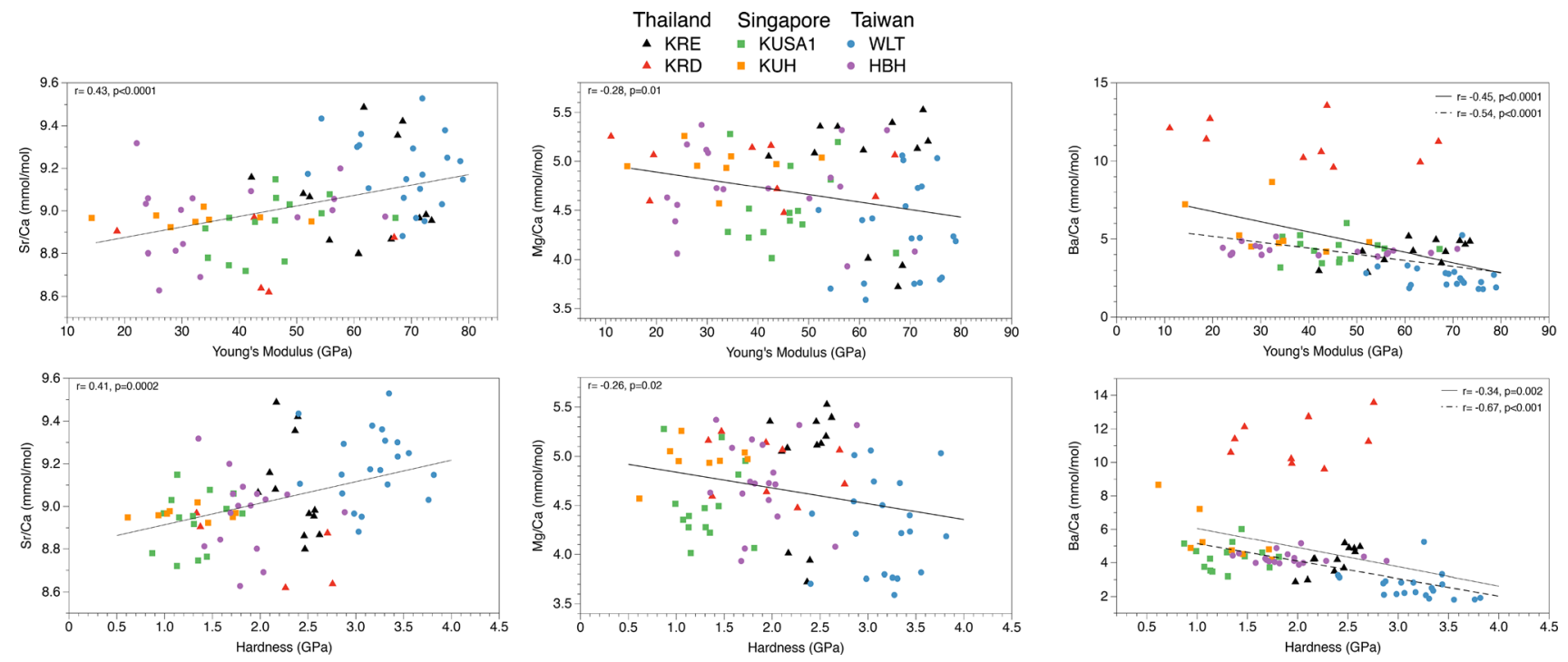

Fig. $7 \mathrm{Sr} / \mathrm{Ca}(\mathrm{mmol} / \mathrm{mol}), \mathrm{Mg} / \mathrm{Ca}(\mathrm{mmol} / \mathrm{mol})$, and $\mathrm{Ba} / \mathrm{Ca}(\mu \mathrm{mol} / \mathrm{mol})$ from sample regions adjacent to nanoindentation areas and corresponding (a) Young's modulus and (b) hardness values from each sampling point along the six Porites cores. Tissue layer data have been excluded from these analyses. $\mathrm{Ba} / \mathrm{Ca}$ regressions are shown with (solid line) and without (dashed line) data from Thailand core KRD

\section{Organic defects and coral skeletal properties}

Several microstructural factors may affect the modulus and hardness, including porosity and micro-flaws, organic content, or weak organic/inorganic and inorganic/inorganic interfaces. The high rate of micro-cracking events observed in Singapore corals, relative to Taiwan and Thailand (Fig. 4a), as well as to previous studies (Goffredo et al. 2014; Pasquini et al. 2015), indicated a more pronounced intrinsic brittleness, and thus, likely a faster erosion rate due to resulting wear damage from micro-cracking (Zok and Miserez 2007).

Organic macromolecules embedded in the coral skeleton play a critical role in biomineralization by acting as a scaffold that not only regulates crystal deposition and growth, but also maintains the geometry of the skeletal structure and re-distributes internal stresses ( $\mathrm{Ji}$ and Gao
2004; Falini et al. 2013; Mass et al. 2017). In a study of bivalve and gastropod shells, an inverse relationship was detected between organic matrix content and material properties, such that shells with higher organic content had decreased hardness and stiffness (Young's modulus) (Fleischli et al. 2008). Comparisons of biogenic and geological aragonite crystals have shown that intra-crystalline organic molecules can induce residual strains and lattice distortions (Pokroy et al. 2006, 2007). Accordingly, a relationship between organic content and skeletal properties has been hypothesized for coral (Goffredo et al. 2014; Pasquini et al. 2015), yet due to a lack of discernible variability in material properties, results were inconclusive. Here, our study provides evidence of an inverse relationship between the annually averaged organic content with both Young's moduli and micro-cracking stress (Fig. 8). While we cannot distinguish between intra- and inter- 
crystalline organics, increasing organic content can increase skeletal flexibility, as organic molecules adhere to minerals and dissipate energy (Wang and Gupta 2011). However, this drives a decrease in hardness and an increase in micro-cracking events, which may deteriorate reef structural integrity and enhance coral's susceptibility to bioerosion.

Based on our organic content analysis, as well as the tendency of corals with higher organic content to exhibit lower moduli, lower hardness, and more frequent microcracking events, we propose that the excess organic content affects mineral growth, resulting in the presence of excessive flaws and/or micro-porosity, and in turn, decreasing the modulus and hardness. Analyzing the molecular composition of coral organic content could reveal whether these trends are driven by a general increase in organic content or an increase in specific organic compounds. Because size and charge of the occluded amino acids can affect the magnitude of intra-crystalline distortions (Kim et al. 2016), the composition and concentration of organic molecules incorporated into the aragonite lattice may alter skeletal stiffness and hardness. Furthermore, it is

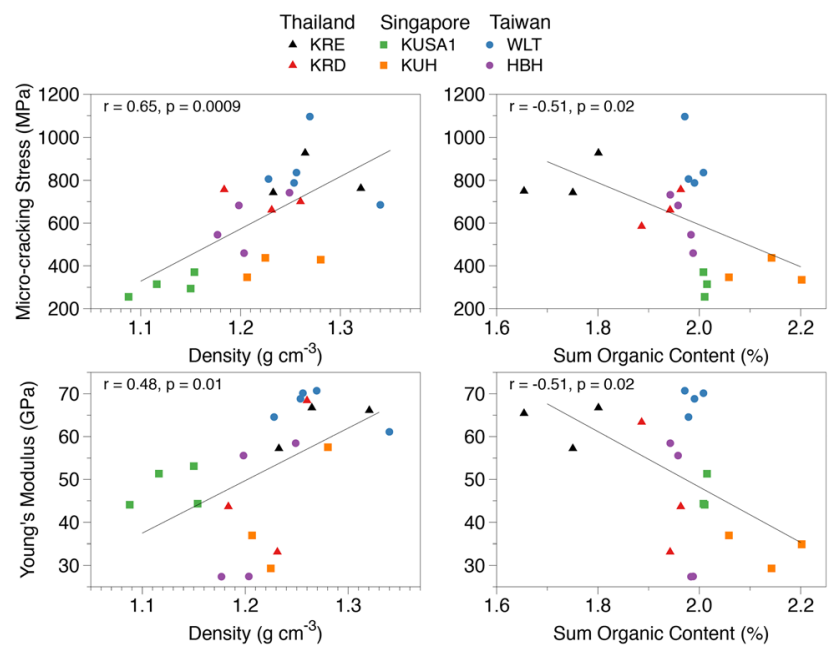

Fig. 8 Correlations between Young's modulus (GPa) and microcracking stress (MPa) with density $\left(\mathrm{g} \mathrm{cm}^{-3}\right)$ and sum organic content (\%). Correlations with organic content data excluded the tissue layer, whereas bulk density correlations included the tissue layer plausible that the incorporation of excess organic compounds that are not involved in regulating biomineral deposition could disrupt the regulating activity of mineralizing proteins, leading to defective crystal growth.

\section{Trace elements and coral skeletal properties}

While intracrystalline organic molecules alter skeletal mechanical properties through intra-crystalline distortions, the organic matrix can also mediate trace metal incorporation in biogenic aragonite (Roger et al. 2017). Trace element impurities may be included in the organic matrix, in an amorphous calcium carbonate phase, or as substitutional defects in the crystal lattice. Such defects can have a strengthening, weakening, or minimal impact on the mechanical properties, depending on their size and concentration (Ma et al. 2008; Kim et al. 2016; Melbourne et al. 2018). In bulk minerals, Young's modulus decreases with increasing cation radius, from $69 \mathrm{GPa}$ (Aragonite, $\mathrm{CaCO}_{3}$ ) to $64 \mathrm{GPa}$ (Strontianite, $\mathrm{SrCO}_{3}$ ) to $48 \mathrm{GPa}$ (Witherite, $\mathrm{BaCO}_{3}$ ) (Biedermann et al. 2017). Computer simulations of $\mathrm{Sr}$ doping in calcite $(0.8$ atom\% $\mathrm{Sr}$, $\sim 8300 \mathrm{ppm})$ and aragonite $(0.6$ atom $\% \mathrm{Sr}, \sim 6250 \mathrm{ppm})$ found considerable changes in calcite, but no effect of $\mathrm{Sr}$ substitution on the aragonite lattice (Stashans et al. 2007). It was hypothesized that higher concentrations were required to detect an effect of $\mathrm{Sr}$ in aragonite (Stashans et al. 2007). In contrast with larger cations, $\mathrm{Mg}$ can increase stiffness and hardness in biominerals; for example, high Young's modulus of calcitic sea urchin teeth is attributed to high $\mathrm{Mg}$ (4.5-13\% Mg calcite plates, 40-45\% Mg polycrystalline matrix) (Ma et al. 2008).

Using skeletal geochemistry, we observed significant correlations between trace element ratios $(\mathrm{M} / \mathrm{Ca})$ and mechanical properties, including $\mathrm{Sr}$ and $\mathrm{Mg}$ (Table 4; Fig. 7). In addition, a relationship between environmental conditions and skeletal mechanics was suggested by the cointegration of Young's modulus and SST (Fig. 6). This trend may reflect an increase in mineralization driven by temperature (Burton and Walter 1987). A similar effect of temperature on material properties has been documented in high Mg-calcite of rhodoliths, whereby Young's modulus and hardness increase in summer (Ma et al. 2008;
Table 5 Correlations between skeleton mechanical and bulk properties (organic content \& density) from the combined 6-core dataset

\begin{tabular}{llll}
\hline & $A 2$ organic content & Sum organic content & Density \\
\hline Young's modulus & $r=-0.42, p=0.07$ & $r=-0.51, p=0.02^{*}$ & $r=0.48, p=0.01^{*}$ \\
Hardness & $r=-0.39, p=0.09$ & $r=-0.31, p=0.20$ & $r=0.53, p=0.01^{* *}$ \\
Micro-fracture stress & $r=-0.47, p=0.09^{*}$ & $r=-0.51, p=0.01^{*}$ & $r=0.65, p=0.0009^{* *}$ \\
Micro-fracture frequency & $r=0.52, p=0.09^{*}$ & $r=0.61, p=0.01^{* *}$ & $r=-0.53, p=0.01^{*}$ \\
\hline
\end{tabular}

Correlations with organic content data excluded the tissue layer, whereas bulk density correlations included the tissue layer

Asterisks denote significance $(0.01<\mathrm{p} \leq 0.05 *, 0.001<\mathrm{p} \leq 0.01 * *)$ 
Melbourne et al. 2018). Moreover, high density bands coincided with summer SSTs within each core, and bulk density correlated with greater Young's modulus and hardness in the combined dataset (Table 5). Accordingly, we expected lower $\mathrm{Sr} / \mathrm{Ca}$ and higher $\mathrm{Mg} / \mathrm{Ca}$ to correspond with greater Young's modulus and hardness, based on established relationships with SST (Smith et al. 1979; Mitsuguchi et al. 1996). Differences in substitution energetics also support this, as smaller (larger) atoms should correspond with greater (lower) mechanical properties (Menadakis et al. 2008; Biedermann et al. 2017). In contrast, when data from all cores were combined, greater Young's moduli and hardness were associated with increased $\mathrm{Sr} / \mathrm{Ca}$, whereas increased $\mathrm{Mg} / \mathrm{Ca}$ and $\mathrm{Ba} / \mathrm{Ca}$ were found in samples with lower moduli and hardness (Fig. 7). Furthermore, bulk density had a positive relationship with $\mathrm{Sr} / \mathrm{Ca}$ (Table 4).

As our sampling was not done along the cores' primary growth axes and elemental ratios were averaged along $0.5 \mathrm{~mm}$ of the laser track (adjacent to indent areas), it is possible that geochemical relationships were obscured by experimental factors (Cohen and Hart 1997). However, while these factors might decrease the reliability and resolution of the SST and $\mathrm{Sr} / \mathrm{Ca}$ relationship, point-to-point comparisons of $\mathrm{M} / \mathrm{Ca}$ with mechanical properties and bulk comparisons are valid. Moreover, for equatorial corals, such as Singapore and Thailand cores, the relationship between $\mathrm{Sr} / \mathrm{Ca}$ and SST is often difficult to establish, and can be highly influenced by low SST variability (Murty et al. 2018). As trends between $\mathrm{M} / \mathrm{Ca}$ and material properties were best observed in the combined 6-core dataset, which had a larger range of trace metal concentrations, these results suggest that either the absolute amount of trace metal substitution or a covarying factor may be impacting structural properties of aragonite.

\section{Mechanisms of skeletal property change}

Changes in elastic modulus for chemically substituted biominerals (such as calcium phosphates) have been predicted by computational modeling and measured experimentally to be $c a$. 10\% (Menéndez-Proupin et al. 2011; Enax et al. 2012). The percentages the major trace elements, $\mathrm{Sr}$ and $\mathrm{Mg}$, in our Porites samples were approximately $0.8 \pm 0.02$ atom $\%$ and $0.1 \pm 0.01$ atom $\% . \mathrm{Ba} / \mathrm{Ca}$ displayed the strongest correlation with Young's modulus and hardness (Fig. 7), yet its concentration in the skeleton was two orders of magnitude lower than $\mathrm{Sr}$ and $\mathrm{Mg}$, accounting for $0.001 \pm 0.002$ atom\%.

While Sr concentrations may be significant enough to slightly alter material properties, we observed up to a $100 \%$ increase in material properties between samples from different locations. Although impurities may affect the mechanical properties in an inhomogeneous manner, given that lattice defects are not uniformly distributed and local deformations can exceed these values (Caspi et al. 2005), trace element substitution alone cannot explain the large variations in elastic modulus and hardness measured in our study. Consequently, correlations between trace element ratios and material properties are likely driven by the environmental and/or biological conditions that elemental substitution represents, rather than by the substitution itself.

In contrast to $\mathrm{Sr}$ and $\mathrm{Mg}$, whose lattice locations within aragonite are well documented ( $\mathrm{Sr}$ substituting for $\mathrm{Ca} ; \mathrm{Mg}$ in an amorphous phase) the location of $\mathrm{Ba}$ in coral aragonite lattice is unknown (Finch et al. 2010; Allison et al. 2018). Recently, a relationship between $\mathrm{Ba} / \mathrm{Ca}$ and organic suspended solids was documented (Tanzil et al. 2019), and our findings support the idea that $\mathrm{Ba}$ is associated with the organic matrix. As corals with higher $\mathrm{Ba} / \mathrm{Ca}$ had decreased stiffness and hardness, $\mathrm{Ba} / \mathrm{Ca}$ likely covaries with a mechanical property altering factor, namely organic content. This is further evidenced by the relationship of $\mathrm{Ba} / \mathrm{Ca}$ with $\mathrm{Mg} / \mathrm{Ca}$, as $\mathrm{Mg} / \mathrm{Ca}$ is known to stabilize amorphous calcium carbonate and is found in higher concentrations in coral centers of calcification, along with organic molecules (Cuif et al. 2003; Meibom et al. 2004; Mass et al. 2014; Von Euw et al. 2017). Pronounced replicate variability in $\mathrm{Ba} / \mathrm{Ca}$ (e.g., Thailand cores KRD, KRE) suggests a strong biological role of $\mathrm{Ba}$ during skeletal incorporation, which is supported by recent findings (Allison et al. 2018; Tanzil et al. 2019).

If $\mathrm{Ba}$ and $\mathrm{Mg}$ observations are associated with skeletal organics and amorphous calcium carbonate, then the positive trends of $\mathrm{Sr}$ with stiffness and hardness could be explained by an increased degree of mineralization, and a corresponding decrease in skeletal organics and amorphous calcium carbonate. Changes in $\mathrm{Sr} / \mathrm{Ca}$ within a given sample were not large enough to alter the mechanical properties and correspondingly, no trend with $\mathrm{Sr} / \mathrm{Ca}$ and material properties was observed within an individual core (Table S3). However, inter-core variability in $\mathrm{Sr} / \mathrm{Ca}$ was 2fold higher than intra-core variability. We hypothesize that the larger $\mathrm{Sr} / \mathrm{Ca}$ range covered by the combined dataset facilitated detection of an effect of $\mathrm{Sr}$ substitution on the material properties of aragonite.

\section{Intra- and inter-site comparisons}

Due to the range in scale and scope of analyses performed on each colony, differences and similarities between replicate cores can be used to disentangle biological effects from environmental signals, facilitating inter-site comparison. For example, Singapore replicate cores were characterized by low moduli and hardness, high rates of microcracking, high organic content, and high $\mathrm{Ba} / \mathrm{Ca}$ and $\mathrm{Mg} / \mathrm{Ca}$. 
The coherence between these cores suggests that Singapore coral mechanical properties are environmentally driven, and could be a result of high sedimentation and runoff rates, which are associated with high $\mathrm{Ba} / \mathrm{Ca}$ and skeletal humic acids (LaVigne et al. 2016; Tanzil et al. 2016, 2019). Singapore is known to experience significant riverine inputs and high sedimentation (Dikou and van Woesik 2006; Tanzil et al. 2019) and also had the lowest salinity of all three sites (Fig. 2).

In contrast, replicate cores from Thailand differed greatly, with $\mathrm{KRD}$ having high $\mathrm{Ba} / \mathrm{Ca}$ and low $\mathrm{Sr} / \mathrm{Ca}$ (Fig. 7), as well as a higher frequency of micro-cracking (Fig. 4). Although the two cores were located approximately $3 \mathrm{~m}$ apart on the same reef and cored at the same time, these differences made it difficult to identify specific environmental influences on the mechanical properties of Thailand corals. Several studies have documented that trace metal incorporation can vary between corals growing in the same conditions, even in corals of the same genotype or the same species cultured in identical conditions (Cole et al. 2016; Allison et al. 2018), which can result from differences in coral growth rates (de Villiers et al. 1995). For example, $\mathrm{Sr} / \mathrm{Ca}$ can be enhanced when an individual coral experiences slower growth relative to adjacent colonies (de Villiers et al. 1995), which we observed between Thailand cores KRD and KRE. Additionally, KRE had lower organic content than KRD. As skeletal organic content can influence both trace element incorporation (Cole et al. 2016) and material properties (Miserez et al. 2009; Amini and Miserez 2013), lower organic content may have contributed to the decrease in micro-cracking stress and frequency in KRE relative to KRD (Fig. 4a). Such variation within replicates suggests that biology or small-scale environmental differences play a large role in controlling both coral geochemistry and coral skeletal mechanical properties.

While Taiwan cores were collected from different reefs, approximately $7 \mathrm{~km}$ apart, they displayed a similar stress and frequency of micro-cracking events, as well as a similar percentage of organic content. Moreover, $\mathrm{HBH}$ was the only core with significant intra-core relationships, with a negative relationship between Young's modulus and organic content. Sampling years with higher organic content also had lower $\mathrm{Sr} / \mathrm{Ca}$, higher $\mathrm{Ba} / \mathrm{Ca}$, and microcracking events that occured at lower loads and with increased frequency. Enhanced seasonal variability of SST, rainfall, and runoff in Taiwan, as well as significantly greater ocean current speed and wave height than other sites, may have facilitated the detection of environmental influences on skeletal mechanical properties at this site.

Despite similarities between Taiwan cores, $\mathrm{HBH}$ was structurally inferior to WLT and displayed no relationship with SST (Fig. 6). These differences may have resulted from distinct hydrodynamic conditions between reefs. Water movement can be beneficial to corals by enhancing primary production and particle capture, removing sediment, mitigating temperature extremes, and enhancing diffusion (Patterson et al. 1991; Sebens et al. 1997; Todd 2008). Corals can modulate calcification in response to flow pressure, as high flow promotes proton export from coral tissue (Jokiel 2011; Comeau et al. 2014). Increased current and wave height at Taiwan sites, particularly at the more exposed reef of WLT, could increase mineralization, Young's modulus, and hardness. In contrast, $\mathrm{HBH}$ is located in a more sheltered bay. This interpretation is further supported when comparing all three sites, as Singapore had the lowest ocean current speed and significant wave height, as well as the lowest moduli and hardness.

\section{Implications for reef structure}

Marine biological structures must be able to sustain loads from external forces, such as wave energy, objection collision and predation, without fracture. Drag and lift forces increase with coral surface area and can become important in massive Porites (Madin 2005), particularly if bioerosion is significant or if the structure has been damaged through micro-cracking events. Yet, for a non-bioeroded hemispherical coral $1 \mathrm{~m}$ in height, a wave approximately $10 \mathrm{~m}$ in height would be required to cause dislodgement (Massel and Done 1993). This is over 5 times greater than the highest significant wave height found at our Taiwan site, and would only be reached during episodic high magnitude wave events (e.g., tsunami, storm surge). Thus, given the shape and compressive strength of coral skeletons, the hydrodynamic fate of an individual colony is often determined not by the strength of its skeleton but by that of the substrate to which it is attached (Madin 2005). Although the likely point of dislodgment occurs at the basal attachment point, the substrate to which corals attach is often coral-derived material, which has undergone taphonomic processes (e.g., bioerosion). Decreased skeletal integrity is likely to further reduce the integrity of coral-derived substrate, ultimately causing to lower amounts of hydrodynamic stress to result in colony dislodgment. While whole-colony dislodgement is typically considered episodic and rare (Madin and Connolly 2006), it is observed seasonally at Kusu Island, Singapore, where the reef is exposed to wind driven swell during the Northeast monsoon (Tanzil et al. 2016). We found that Singapore Porites from Kusu had lower skeletal hardness and stiffness and higher brittleness, as shown by the rate of micro-cracking, which likely also translates to lower quality reef substrate. Although wave energy and dislodgement probability decrease significantly with distance from the reef crest (Madin and Connolly 2006; Madin et al. 2006), the reef at Kusu only spans approximately $100 \mathrm{~m}$, between a 
seawall and the slope, causing the majority of the reef to experience crest like conditions. Annual dislodgement probability estimates approach zero for a variety of coral morphologies between 50 and $100 \mathrm{~m}$ from the reef crest (Madin and Connolly 2006). Consequently, due to reef morphology and increased organic content, Singapore's corals may be more at risk of dislodgement than the other reefs in this study. Dislodgement not only overturns individual colonies, but dislodged colonies can also collide with adjacent corals, causing broader reef damage. Additional studies should characterize the mechanical properties of other important reef-building and substrate-forming corals, particularly of those with different growth rates, such as branching corals, to determine if other species have such a large range in material properties.

In addition to hydrodynamic forces, microborers, macroborers, and grazers can cause skeletal fracture and bioerosion (Tribollet and Golubic 2005). For example, certain species of parrotfish and urchins are known to selectively graze on Porites colonies (Bonaldo and Bellwood 2010). In contrast with wave compressive forces, which are often several orders of magnitude less than skeletal strength, the stiffness and hardness of parrotfish enameloid $(E=124 \mathrm{GPa} ; \quad H=7.3 \mathrm{GPa})$ and urchin teeth ( $E=100 \mathrm{GPa} ; H=6 \mathrm{GPa}$ ) greatly surpass that of coral, as well as the coral skeleton's resistance against microcracking (Amini and Miserez 2013; Marcus et al. 2016). Frictional forces exerted by grazing organisms and macroborers are most relevant to the coral structure, as they are typically sufficient to erode the skeleton by micro-cracking events, and can even increase the probability of dislodgement by changing the shape of massive colonies (Glynn and Manzello 2015; Madin 2005). The resistance against wear and abrasion-a complex interplay between Young's modulus, hardness, fracture toughness, and contact geometry-is the key material characteristic controlling structural damage (Amini and Miserez 2013). If the coral is significantly embrittled, as measured here in samples from the Kusu reef (Singapore), faster erosion is expected, resulting in accelerated decrease in reef substrate quality and increasing colony dislodgement and macro-scale reef damage (Zok and Miserez 2007; Momber 2001).

Understanding what drives differences in mechanical properties of coral skeletons can improve our fundamental knowledge of reef structural stability, coral biomineralization, and geochemistry. We found large and unexpected variability in material properties, as well as significantly different properties between the tissue and fully formed skeleton, highlighting the need to distinguish these layers in future studies. Organic matrix content and/or $\mathrm{Sr}$ substitution in the aragonite lattice may drive changes in skeletal stiffness, hardness, and embrittlement. Moreover, organic content and its proxy, $\mathrm{Ba} / \mathrm{Ca}$, suggest that increasing runoff, sedimentation, rainfall or feeding could increase a skeleton's tendency to incur irreversible damage via cumulative microcracking events. While massive Porites skeletons can withstand wave forces well beyond average storm surges, in building a stiff skeleton, corals contribute high quality material to reef substrate and decrease the rate of bioerosion by predators and borers. Coral skeletal properties can thus be considered a balance between colony dislodgement, predation, erosion, and access to light and nutrients. However, reefs are predicted to experience increased storm frequency, in addition to the pressures of anthropogenic pollution, sedimentation, and coastal development (Hoegh-Guldberg et al. 2007). These changes will not only impact the health of the living organism but may also impact the structural integrity of its skeleton and stability of the reef substrate itself. Future studies should aim to characterize micro- and nano-mechanical properties of coral skeletons across a range of species and environments, to determine if the characteristics of Porites skeletons reported here are also common among other key reef-building taxa.

Acknowledgements We thank the Earth Observatory of Singapore, Asian School of the Environment, Nanyang Technological University, National Research Foundation Singapore (NRF-RF2012-03), Singapore Ministry of Education, Research Centers of Excellence initiative, and the Marine Science R\&D Programme (MSRDP-P03 and MSRDP-P29) for financial and logistical support. Thanks to the Phuket Marine Biological Centre and the National Research Council of Thailand (Proj. ID 2009/043), and the Singapore National Parks (NP/RP16-156-2a). Many thanks to Jeff Oalmann for assistance with the Iolite software, and to Kyle M. Morgan and Riovie Ramos for thoughtful discussions. This work comprises Earth Observatory of Singapore contribution 347.

\section{Compliance with ethical standards}

Conflicts of interest The authors declare that they have no conflict of interest.

Open Access This article is licensed under a Creative Commons Attribution 4.0 International License, which permits use, sharing, adaptation, distribution and reproduction in any medium or format, as long as you give appropriate credit to the original author(s) and the source, provide a link to the Creative Commons licence, and indicate if changes were made. The images or other third party material in this article are included in the article's Creative Commons licence, unless indicated otherwise in a credit line to the material. If material is not included in the article's Creative Commons licence and your intended use is not permitted by statutory regulation or exceeds the permitted use, you will need to obtain permission directly from the copyright holder. To view a copy of this licence, visit http://creativecommons. org/licenses/by/4.0/.

\section{References}

Acker JG, Leptoukh G (2007) Online analysis enhances use of NASA earth science data. EOS 88:14 
Addadi L, Raz S, Weiner S (2003) Taking advantage of disorder: amorphous calcium carbonate and its roles in biomineralization. Adv Mater 15:959-970

Akiva A, Neder M, Kahil K, Gavriel R, Pinkas I, Goobes G, Mass T (2018) Minerals in the pre-settled coral Stylophora pistillata crystallize via protein and ion changes. Nat Commun 9:1880

Allison N, Finch AA (2010) B, Sr, Mg and B in a modern Porites coral: the relationship between calcification site $\mathrm{pH}$ and skeletal chemistry. Geochim Cosmochim Acta 74(6):1790-1800

Allison N, Cole C, Hintz C, Hintz K, Finch AA (2018) Influences of coral genotype and seawater $\mathrm{pCO}_{2}$ on skeletal $\mathrm{Ba} / \mathrm{Ca}$ and $\mathrm{Mg} / \mathrm{Ca}$ in cultured massive Porites spp. corals. Palaeogeogr Palaeoclimatol Palaeoecol 505:351-358

Amini S, Miserez A (2013) Wear and abrasion resistance selection maps of biological materials. Acta Biomater 9:7895-7907

Baldock TE, Karampour H, Sleep R, Vyltla A, Albermani F, Golshani A, Callaghan DP, Roff G, Mumby PJ (2014) Resilience of branching and massive corals to wave loading under sea level rise-a coupled computational fluid dynamics-structural analysis. Mar Pollut Bull 86:91-101

Benzerara K, Menguy N, Obst M, Stolarski J, Mazur M, Tylisczak T, Brown GE, Meibom A (2011) Study of the crystallographic architecture of corals at the nanoscale by scanning transmission $\mathrm{X}$-ray microscopy and transmission electron microscopy. Ultramicroscopy 111:1268-1275

Biedermann N, Winkler B, Speziale S, Reichmann HJ, Koch-Müller M (2017) Single-crystal elasticity of $\mathrm{SrCO}_{3}$ by Brillouin spectroscopy. High Press Res 37:181-192

Bonaldo RM, Bellwood DR (2010) Parrotfish predation on massive Porites on the Great Barrier Reef. Coral Reefs 30(1):259-269

Burton EA, Walter LM (1987) Relative precipitation rates of aragonite and $\mathrm{Mg}$ calcite from seawater: temperature or carbonate ion control? Geology 15:111

Caroselli E, Prada F, Pasquini L, Marzano FN (2011) Environmental implications of skeletal micro-density and porosity variation in two scleractinian corals. Zoology 5:255-264

Carton JA, Giese BS (2008) A reanalysis of ocean climate using simple ocean data assimilation (SODA). Mon Weather Rev 136:2999-3017

Caspi EN, Pokroy B, Lee PL, Quintana JP, Zolotoyabko E (2005) On the structure of aragonite. Acta Crystallogr B 61:129-132

Chamberlain JA (1978) Mechanical properties of coral skeleton: compressive strength and its adaptive significance. Paleobiology $4: 419-435$

Cohen AL, Hart SR (1997) The effect of colony topography on climate signals in coral skeleton. Geochim Cosmochim Acta 61(18):3905-3912

Cole C, Finch A, Hintz C, Hintz K, Allison N (2016) Understanding cold bias: variable response of skeletal $\mathrm{Sr} / \mathrm{Ca}$ to seawater $\mathrm{pCO}_{2}$ in acclimated massive Porites corals. Sci Rep 6:26888

Comeau S, Edmunds PJ, Lantz CA, Carpenter RC (2014) Water flow modulates the response of coral reef communities to ocean acidification. Sci Rep 4:6681

Cuif JP, Dauphin Y (2005) The two-step mode of growth in the scleractinian coral skeletons from the micrometre to the overall scale. J Struct Biol 150(3):319-331

Cuif JP, Dauphin Y, Doucet J, Salome M, Susini J (2003) XANES mapping of organic sulfate in three scleractinian coral skeletons. Geochim Cosmochim Acta 67:75-83

Cuif JP, Dauphin Y, Berthet P, Jegoudez J (2004) Associated water and organic compounds in coral skeletons: quantitative thermogravimetry coupled to infrared absorption spectrometry. Geochem Geophys Geosyst 5:1-9

Dauphin Y, Cuif JP, Massard P (2006) Persistent organic components in heated coral aragonitic skeletons-implications for palaeoenvironmental reconstructions. Chem Geol 231:26-37
DeCarlo TM, Ren H, Farfan GA (2018) The origin and role of organic matrix in coral calcification: insights from comparing coral skeleton and abiogenic aragonite. Front Mar Sci 5:1129

Dikou A, van Woesik R (2006) Survival under chronic stress from sediment load: Spatial patterns of hard coral communities in the southern islands of Singapore. Mar Pollut Bull 52:7-21

Druffel ERM (1997) Geochemistry of corals: proxies of past ocean chemistry, ocean circulation, and climate. PNAS 94:8354-8361

Enax J, Prymak O, Raabe D, Epple M (2012) Structure, composition, and mechanical properties of shark teeth. J Struct Biol 178:290-299

Falini G, Reggi M, Fermani S, Sparla F, Goffredo S, Dubinsky Z, Levi O, Dauphin Y, Cuif JP (2013) Control of aragonite deposition in colonial corals by intra-skeletal macromolecules. J Struct Biol 183:226-238

Falini G, Fermani S, Goffredo S (2015) Coral biomineralization: a focus on intra-skeletal organic matrix and calcification. Semin Cell Dev Biol 46:17-26

Fantazzini P, Mengoli S, Pasquini L, Bortolotti V (2015) Gains and losses of coral skeletal porosity changes with ocean acidification acclimation. Nature 6:7785

Finch AA, Allison N, Steaggles H, Wood CV, Mosselmans JFW (2010) Ba XAFS in Ba-rich standard minerals and the potential for determining Ba structural state in calcium carbonate. Chem Geol 270:179-185

Fleischli FD, Dietiker M, Borgia C, Spolenak R (2008) The influence of internal length scales on mechanical properties in natural nanocomposites: a comparative study on inner layers of seashells. Acta Biomater 4:1694-1706

Glynn PW, Manzello DP (2015) Bioerosion and coral reef growth: a dynamic balance. In: Birkeland $\mathrm{C}$ (ed) Coral reefs in the anthropocene. Springer, Dordrecht, pp 67-97

Goffredo S, Mancuso A, Caroselli E, Prada F, Dubinsky Z, Falini G, Levy O, Fantazzini P, Pasquini L (2014) Skeletal mechanical properties of Mediterranean corals along a wide latitudinal gradient. Coral Reefs 34:121-132

Graham NAJ, Nash KL (2012) The importance of structural complexity in coral reef ecosystems. Coral Reefs 32(2):315-326

Grottoli AG (2001) Past climate from corals. Encyclopedia of Ocean Sciences, London, pp 2098-2107

Hoegh-Guldberg O, Mumby PJ, Hooten AJ, Steneck RS, Greenfield P, Gomez E, Harvell CD, Sale PF, Edwards AJ, Caldeira K, Knowlton N, Eakin CM, Iglesias-Prieto R, Muthiga N, Bradbury RH, Dubi A, Hatziolos ME (2007) Coral reefs under rapid climate change and ocean acidification. Science 318:1737-1742

Hoegh-Guldberg O, Poloczanska ES, Skirving W, Dove S (2017) Coral reef ecosystems under climate change and ocean acidification. Front Mar Sci 4:158

Holcomb M, Cohen AL, Gabitov RI, Hutter JL (2009) Compositional and morphological features of aragonite precipitated experimentally from seawater and biogenically by corals. Geochim Cosmochim Acta 73:4166-4179

Hughes TP, Anderson KD, Connolly SR, Heron SF, Kerry JT, Lough JM, Baird AH, Baum JK, Berumen ML, Bridge TC, Claar DC, Eakin CM, Gilmour JP, Graham NAJ, Harrison H, Hobbs JPA, Hoey AS, Hoogenboom M, Lowe RJ, McCulloch MT, Pandolfi JM, Pratchett M, Schoepf V, Torda G, Wilson SK (2018) Spatial and temporal patterns of mass bleaching of corals in the anthropocene. Science 359(6371):80-83

Ji B, Gao H (2004) Mechanical properties of nanostructure of biological materials. J Mech Phys Solids 52:1963-1990

Johnson JA, Perry CT, Smithers SG, Morgan KM, Santodomingo N, Johnson KG (2017) Palaeoecological records of coral community development on a turbid, nearshore reef complex: baselines for assessing ecological change. Coral Reefs 36(3):685-700 
Jokiel PL (2011) Ocean acidification and control of reef coral calcification by boundary layer limitation of proton flux. Bull Mar Sci 87:639-657

Kearney C, Zhao Z, Bruet BJF, Radovitzky R, Boyce MC, Ortiz C (2006) Nanoscale anisotropic plastic deformation in single crystal aragonite. Phys Rev Lett 96:255505

Kim YY, Carloni JD, Demarchi B, Sparks D, Reid DG, Kunitake ME, Tang CC, Duer MJ, Freeman CL, Pokroy B, Penkman K, Harding JH, Estroff LA, Baker SP, Meldrum FC (2016) Tuning hardness in calcite by incorporation of amino acids. Nat Mater 15:903-910

LaVigne M, Grottoli AG, Palardy JE, Sherrell RM (2016) Multicolony calibrations of coral $\mathrm{Ba} / \mathrm{Ca}$ with a contemporaneous in situ seawater barium record. Geochim Cosmochim Acta 179:203-216

Liu Z, Meyers MA, Zhang Z, Ritchie RO (2017) Functional gradients and heterogeneities in biological materials: Design principles, functions, and bioinspired applications. Prog Mater Sci $88: 467-498$

Lough JM, Barnes DJ (1990) Intra-annual timing of density band formation of Porites coral from the central Great Barrier Reef. J Exp Mar Bio Ecol 135:35-57

Lough J, Barnes D, Devereux M, Tobin B, Tobin S (1999) Variability in growth characteristics of massive Porites on the Great Barrier Reef. CRC Reef Res Centre Ltd Technical Rep 28:1-95

Ma Y, Cohen SR, Addadi L, Weiner S (2008) Sea urchin tooth design: an "all-calcite" polycrystalline reinforced fiber composite for grinding rocks. Adv Mater 20:1555-1559

Madin JS (2005) Mechanical limitations of reef corals during hydrodynamic disturbances. Coral Reefs 24:630-635

Madin JS, Connolly SR (2006) Ecological consequences of major hydrodynamic disturbances on coral reefs. Nature 444:477-480

Madin JS, Black KP, Connolly SR (2006) Scaling water motion on coral reefs: from regional to organismal scales. Coral Reefs 25:635-644

Mallela J, Lewis SE, Croke B (2013) Coral skeletons provide historical evidence of phosphorus runoff on the Great Barrier Reef. PLoS ONE 8:e75663

Marcus MA, Amini S, Stifler CA, Sun CY, Tamura N, Bechtel HA, Parkinson DY, Barnard HS, Zhang XXX, Chua JQI, Miserez A, Gilbert PUPA (2016) Parrotfish teeth: stiff biominerals whose microstructure makes them tough and abrasion-resistant to bite stony corals. ACS Nano 11:11856-11865

Mass T, Drake JL, Peters EC, Jiang W, Falkowski PG (2014) Immunolocalization of skeletal matrix proteins in tissue and mineral of the coral Stylophora pistillata. PNAS 111:12728-12733

Mass T, Giuffre AJ, Sun CY, Stifler CA, Frazier MJ, Neder M, Tamura N, Stan CV, Marcus MA, Gilbert PUPA (2017) Amorphous calcium carbonate particles form coral skeletons. PNAS 114:E7670-E7678

Massel SR, Done TJ (1993) Effects of cyclone waves on massive coral assemblages on the Great Barrier Reef: meteorology, hydrodynamics and demography. Coral Reefs 12:153-166

Meibom A, Cuif JP, Hillion F, Constantz BR, Juillet-Leclerc A, Dauphin Y, Watanabe T, Dunbar RB (2004) Distribution of magnesium in coral skeleton. Geophys Res Lett 31:L23306

Melbourne LA, Denny MW, Harniman RL, Rayfield EJ, Schmidt DN (2018) The importance of wave exposure on the structural integrity of rhodoliths. J Exp Mar Bio Ecol 503:109-119

Menadakis M, Maroulis G, Koutsoukos PG (2008) Incorporation of $\mathrm{Mg}^{2+}, \mathrm{Sr}^{2+}, \mathrm{Ba}^{2+}$ and $\mathrm{Zn}^{2+}$ into aragonite and comparison with calcite. J Math Chem 46:484-491

Menéndez-Proupin E, Cervantes-Rodríguez S, Osorio-Pulgar R, Franco-Cisterna M, Camacho-Montes H, Fuentes M (2011)
Computer simulation of elastic constants of hydroxyapatite and fluorapatite. J Mech Behav Biomed Mater 4:1011-1020

Miserez A, Weaver JC, Pedersen PB, Schneeberk T, Hanlon RT, Kisailus D, Birkedal H (2009) Microstructural and biochemical characterization of the nanoporous sucker rings from Dosidicus gigas. Adv Mater 21:401-406

Mitsuguchi T, Matsumoto E, Abe O, Uchida T (1996) $\mathrm{Mg} / \mathrm{Ca}$ thermometry in coral skeletons. Science 274:961-963

Moberg F, Folke C (1999) Ecological goods and services of coral reef ecosystems. Ecol Econ 29:215-233

Momber A (2001) Stress-strain relation for water-driven particle erosion of quasi-brittle materials. Theoret Appl Fract Mech 35(1):19-37

Morgan KM, Moynihan MA, Sanwlani N, Switzer AD (2020) Light limitation and depth-variable sedimentation drives vertical reef compression on turbid coral reefs. Front Mar Sci 7:571256

Mu G, Duan F, Zhang G, Li X, Ding X, Zhang L (2018) Microstructure and mechanical property of Ruditapes philippinarum shell. J Mech Behav Biomed Mater 85:209-217

Murty SA, Goodkin NF, Wiguna AA, Gordon AL (2018) Variability in coral-reconstructed sea surface salinity between the Northern and Southern Lombok Strait linked to East Asian Winter Monsoon Mean State Reversals. Paleoceanography 33:1116-1133

Muscatine L, Tambutté E, Allemand D (1997) Morphology of coral desmocytes, cells that anchor the calicoblastic epithelium to the skeleton. Coral Reefs 16:205-213

Oliver WC, Pharr GM (2004) Measurement of hardness and elastic modulus by instrumented indentation: advances in understanding and refinements to methodology. J Mater Res 19:3-20

Pasquini L, Molinari A, Fantazzini P, Dauphen Y, Cuif JP, Levy O, Dubinsky Z, Caroselli E, Prada F, Goffredo S, Di Giosia M, Reggi M, Falini G (2015) Isotropic microscale mechanical properties of coral skeletons. J R Soc Interface 12:20150168

Patterson MR, Sebens KP, Olson RR (1991) In situ measurements of flow effects on primary production and dark respiration in reef corals. Limnol Oceanogr 36:936-948

Pokroy B, Fitch AN, Marin F, Kapon M, Adir N, Zolotoyabko E (2006) Anisotropic lattice distortions in biogenic calcite induced by intra-crystalline organic molecules. J Struct Biol 155:96-103

Pokroy B, Fieramosca JS, Von Dreele RB, Fitch AN, Caspi EN, Zolotoyabko E (2007) Atomic structure of biogenic aragonite. Chem Mater 19:3244-3251

Politi Y, Batchelor DR, Zaslansky P, Chmelka BF, Weaver JC, Sagi I, Weiner S, Addadi L (2010) Role of magnesium ion in the stabilization of biogenic amorphous calcium carbonate: a structure-function investigation. Chem Mater 22:161-166

Pratchett MS, Munday P, Wilson S, Graham NA, Cinner JE, Bellwood DR, Jones GP, Polunin NV, McClanahan TR (2008) Effects of climate-induced coral bleaching on coral-reef fishes. Oceanogr Mar Biol Ann Rev 46:251-296

R Core Team (2019) R: a language and environment for statistical computing. R Foundation for Statistical Computing, Vienna, Austria, https://www.R-project.org/

Ragazzola F, Foster LC, Jones CJ, Scott TB, Fietzke J, Kilburn MR, Schmidt DN (2016) Impact of high $\mathrm{CO}_{2}$ on the geochemistry of the coralline algae Lithothamnion glaciale. Sci Rep 6:20572

Ramos RDP (2019) Coral-based reconstruction of climatic and oceanographic variability across the Luzon Strait for the past 230 years. PhD thesis, Nanyang Technological University

Rayner NA, Parker DE, Horton EB, Folland CK, Alexander LV, Rowell DP, Kent EC, Kaplan A (2003) Global analyses of sea surface temperature, sea ice, and night marine air temperature since the late Nineteenth Century. J Geophys Res 108:4407 37pp

Roger LM, George AD, Shaw J, Hart RD, Roberts M, Becker T, McDonald BJ, Evans NJ (2017) Geochemical and 
microstructural characterisation of two species of cool-water bivalves (Fulvia tenuicostata and Soletellina biradiata) from Western Australia. Biogeosciences 14:1721-1737

Sebens KP, Witting J, Helmuth B (1997) Effects of water flow and branch spacing on particle capture by the reef coral Madracis mirabilis (Duchassaing and Michelotti). J Exp Mar Bio Ecol 211:1-28

Silbiger NJ, Nelson CE, Remple K, Sevilla JK, Quinlan ZA, Putnam HM, Fox MD, Donahue MJ (2018) Nutrient pollution disrupts key ecosystem functions on coral reefs. Proc R Soc B Biol Sci 285(1880):20172718-9

Smith SV, Buddemeier RW, Redalje RC, Houck JE (1979) Strontium-calcium thermometry in coral skeletons. Science 204:404-407

Stashans A, Chamba G, Pinto H (2007) Electronic structure, chemical bonding, and geometry of pure and $\mathrm{Sr}$-doped $\mathrm{CaCO}_{3}$. J Comput Chem 29:343-349

Tambutté E, Allemand D, Zoccola D, Meibom A, Lotto S, Caminiti N, Tambutté S (2007) Observations of the tissue-skeleton interface in the scleractinian coral Stylophora pistillata. Coral Reefs 26:517-529

Tanzil JTI, Brown BE, Dunne RP, Lee JN, Kaandorp JA, Todd PA (2013) Regional decline in growth rates of massive Porites corals in Southeast Asia. Glob Change Biol 19(10):3011-3023

Tanzil JTI, Lee JN, Brown BE, Quax R, Kaandorp JA, Lough JM, Todd PA (2016) Luminescence and density banding patterns in massive Porites corals around the Thai-Malay Peninsula, Southeast Asia. Limnol Oceanogr 61:2003-2026

Tanzil JTI, Goodkin NF, Sin TM, Chen ML, Fabbro GN, Boyle EA, Lee AC, Toh KB (2019) Multi-colony coral skeletal Ba/Ca from Singapore's turbid urban reefs: relationship with contemporaneous in-situ seawater parameters. Geochim Cosmochim Acta 250:191-208
Todd PA (2008) Morphological plasticity in scleractinian corals. Biol Rev 83:315-337

Tolman HL (2002) User manual and system documentation of WAVEWATCH III version 2.22. Tech Note $\mathrm{p} 133$

Tribollet A, Golubic S (2005) Cross-shelf differences in the pattern and pace of bioerosion of experimental carbonate substrates exposed for 3 years on the northern Great Barrier Reef, Australia. Coral Reefs 24:422-434

Van Vliet KJ, Li J, Zhu T, Yip S, Suresh S (2003) Quantifying the early stages of plasticity through nanoscale experiments and simulations. Phys Rev B 67:104105

Vernon J (2000) Corals of the world. Australian Institute of Marine Science, Townsville

de Villiers S, Nelson BK, Chivas AR (1995) Biological controls on coral $\mathrm{Sr} / \mathrm{Ca}$ and $\delta^{18} \mathrm{O}$ reconstructions of sea surface temperatures. Science 269:1247-1249

Von Euw S, Zhang Q, Manichev V, Murali N, Gross J, Feldman LC, Gustafsson T, Flach C, Mendelsohn R, Falkowski PG (2017) Biological control of aragonite formation in stony corals. Science 356:933-938

Wang R, Gupta HS (2011) Deformation and fracture mechanisms of bone and nacre. Annu Rev Mater Res 41:41-73

Weber JN, Deines P, White EW, Weber PH (1975) Seasonal high and low-density bands in reef coral skeletons. Nature 255:697-698

Zhang T, Ma Y, Chen K, Kunz M, Tamura N, Qiang M, Xu J, Qi L (2011) Structure and mechanical properties of a pteropod shellf consisting of interlocked helical aragonite nanofibers. Angew Chem Int Ed 50:10361-10365

Zok FW, Miserez A (2007) Property maps for abrasion resistance of materials. Acta Mater 55:6365-6371

Publisher's Note Springer Nature remains neutral with regard to jurisdictional claims in published maps and institutional affiliations. 